\title{
Regeneration of nutrients and biological productivity in Antarctic waters
}

\author{
X. N. Verlencar ${ }^{1}$, K. Somasunder ${ }^{1}$, S. Z. Qasim ${ }^{2}$ \\ ${ }^{1}$ National Institute of Oceanography, Dona Paula, Goa 403 004, India \\ ${ }^{2}$ Jamia Millia Islamia, Central University, Jamia Nagar, New Delhi 110 025, India
}

\begin{abstract}
Watermass structure, productivity and nutrient characteristics are presented for Antarctic water adjoining the Indian Ocean, between 11 and $53^{\circ} \mathrm{E}$ longitude, based on data collected during 4 expeditions from 1982 to 1986 . From contours of potential temperature, salinity, and potential density and nutrients, the Subtropical Convergence (STC) zone is located around 42 to $38^{\circ} \mathrm{S}$ and the Antarctic Convergence $(\mathrm{AC})$ zone between 53 and $46^{\circ} \mathrm{S}$. In the Divergence region, which occurs around $65^{\circ} \mathrm{S}$, nutrient-rich Warm Deep Water is brought to the surface. Nitrate and phosphate isoplets indicate the dominance of physical mixing processes over biological processes. Markedly high chlorophyll (chl a) and primary productivity (PP) values in the coastal ice edge zone (mean surface values: chl $a_{1} 1.60 \pm$ $1.03 \mathrm{mg} \mathrm{m}^{-3} ; \mathrm{PP}, 1.61 \pm 1.0 \mathrm{mg} \mathrm{C} \mathrm{m}^{-3} \mathrm{~h}^{-1}$ ) compared to those in the oceanic region (mean chl $a, 0.30 \pm$ $0.09 \mathrm{mg} \mathrm{m}{ }^{-3}$; PP, $0.3 \pm 0.06 \mathrm{mg} \mathrm{C} \mathrm{m}^{-3} \mathrm{~h}^{-1}$ ) suggest that the coastal waters are far more productive. Measurements on a transect from 69 to $30^{\circ} \mathrm{S}$ indicate that the Antarctic region south of the Convergence (south of $58^{\circ} \mathrm{S}$ ) is a highly productive zone. A sharp decrease in the silica concentration from the divergence up to the STC indicates a higher demand of this nutrient by Antarctic diatoms. Positive anomalies of non-conservative parameters like nitrate, phosphate and silicate show that the atomic $\Delta N /$ $\Delta \mathrm{P}$ ratio south of STC is 10, whereas $\Delta \mathrm{Si} / \Delta \mathrm{N}$ shows 2 slopes in this region reflecting the difference in silica regeneration rates in subsurface and deep Antarctic waters. The $\Delta \mathrm{Si} / \Delta \mathrm{N}$ oxidative ratio in the region south of STC shows a 5 -fold increase as compared to the region north of it. The changes in the 2 regions may reflect the difference in the regeneration processes of these nutrients. From the $\Delta N / \Delta P$ anomaly and oxidative ratios it can be concluded that the silica remineralisation is high in the region south of the STC and is mostly confined to the Antarctic subsurface waters.
\end{abstract}

\section{INTRODUCTION}

Earlier studies on hydrography and nutrient distribution have contributed useful information towards a broad classification of the watermass structure and productivity of Antarctic waters (El-Sayed 1967. Gordon \& Goldberg 1970, Deacon 1982). However, detailed studies on the physico-chemical and biological characteristics have been conducted only in a few areas such as the Weddell Sea, Drake Passage and Scotia Sea (Deacon 1977, El-Sayed \& Taguchi 1981, Ronner et al. 1983), Ross Sea (Biggs 1982, Smith \& Nelson 1985) and some regions of the Indian Ocean sector (Gambaroni et al. 1982, Le Jahan \& Treguer 1985).

From these studies it has been concluded that the hydrographic features in the Antarctic waters are governed by surfacing of the main oceanic thermocline and by the strong deep-reaching circumpolar current.
The waters south of the Polar Front are characterised by low temperature in the range +4.5 to $-2{ }^{\circ} \mathrm{C}$ and high nutrient concentration. These are sustained by large-scale upwelling and turbulent mixing in the upper water column (Deacon 1982). While phytoplankton productivity in the Antarctic waters in general remains low (Walsh 1971, Slawyk 1979, El-Sayed \& Taguchi 1981), there are indications that concentrations of silicates, and at times of nitrates, in the surface waters of the Subantarctic region may reach limiting levels for phytoplankton growth (Kuramoto \& Koyama 1982, Jacques 1983, Le Jehan \& Treguer 1985. Sommer 1986, Sommer \& Stabel 1986).

However, at deeper layers, between the northward movement of Antarctic Intermediate Water and the southward movement of the more saline Deep Warm Water, phosphate, nitrate and silicate appear to be regenerated possibly because of the decay of sinking phytoplankton debris, as indicated by the abundant 
deposits of diatom ooze in the Antarctic sediments (De Master 1981). Biological activity accompanied by physical mixing processes in the euphotic layer may bring about several interesting features of organic matter transformation. Unlike other upwelling regions off Peru (Friederich \& Codispoti 1981) and northwest Africa (Nelson et al. 1981), very little data are available on these processes for Antarctic waters (Le Jehan \& Treguer 1985), which support high standing stocks of krill seabirds, seals and whales

The present investigation studied oceanographic features and their relation to planktonic productivity and nutrient regeneration processes in the relatively unexplored regions of the Antarctic waters adjoining the Indian Ocean between 11 and $53^{\circ}$ E longitude. Data were collected from various Indian Antarctic Expeditions (INAEX 1 to $V$; Fig. 1), during austral summers from 1982 to 1986 ).

\section{MATERIAL AND METHODS}

Sampling was usually restricted to the return voyage of the ship for INAEX I, III and V expeditions. Sampling periods were 18 January to 8 February 1982 for INAEX I, 3 to 6 March 1984 for INAEX III, and 3 to 10 March. 1986 for INAEX V. Oceanographic observations in the euphotic zone during INAEX IV were made in the region from $60^{\circ} \mathrm{S}$ southwards during the ship's outward journey to Antarctica and in the polynia near the coastal ice edge between 23 December 1984 and 10 February 1985, and during the return voyage from 3 to 12 March 1985. Due to limited shiptime it was not possible to sample more stations along the latitudinal transect. However, XBT profiles and sea surface temperature during INAEX I was taken at intervals of less than $1^{\circ}$ latitude along the entire cruise track (not shown in Fig. 1a). Hydrographic data were obtained using Niskin bottles fitted with reversing thermometers. For the computation of potential temperature the algorithms of Fofonoff \& Millard (1983) were used, and apparent oxygen utilisation (AOU) was computed from the nomogram of Benson \& Krauss (1984). Multiple regression analysis was carried out for dissolved oxygen, potential temperature $(\theta)$ and phosphate. Oxygen residuals were calculated using the following equation:

$$
\mathrm{O}_{2} \text { (res) }=\mathrm{O}_{2} \text { (obs) }-\mathrm{a}_{0}+\mathrm{a}_{1} \mathrm{PO}_{4}+\mathrm{a}_{2} \theta
$$

where $\mathrm{O}_{2}$ (obs) = observed oxygen value in $\mu \mathrm{M}_{;} \mathrm{a}_{0}$. $\mathrm{a}_{1}$ and $\mathrm{a}_{2}=$ multiple regression coefficients (AlvarezBorrego et al. 1975). Linear mixing relationships of the water masses were identified with the help of $\theta$ salinity plots. Based on the end member characteristics of the 2 water masses, the nutrient anomalies were derived from the difference between observed and calculated nutrient values. For primary productivity and chlorophyll a measurements, during the first and the fourth Antarctic Expeditions (INAEX I \&

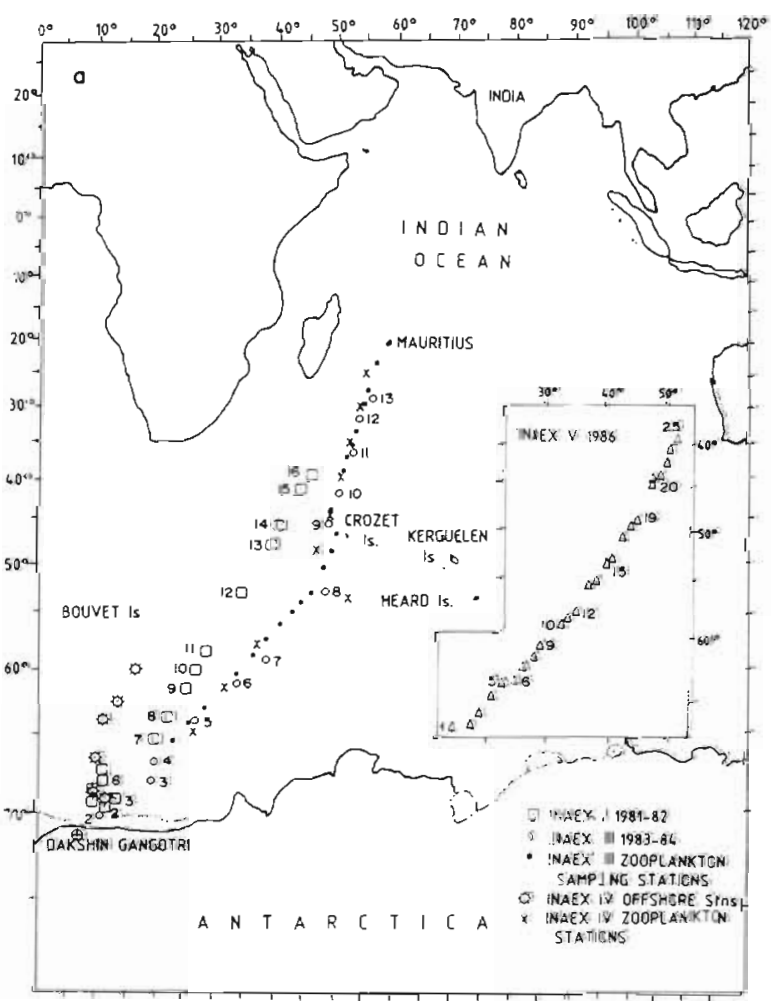

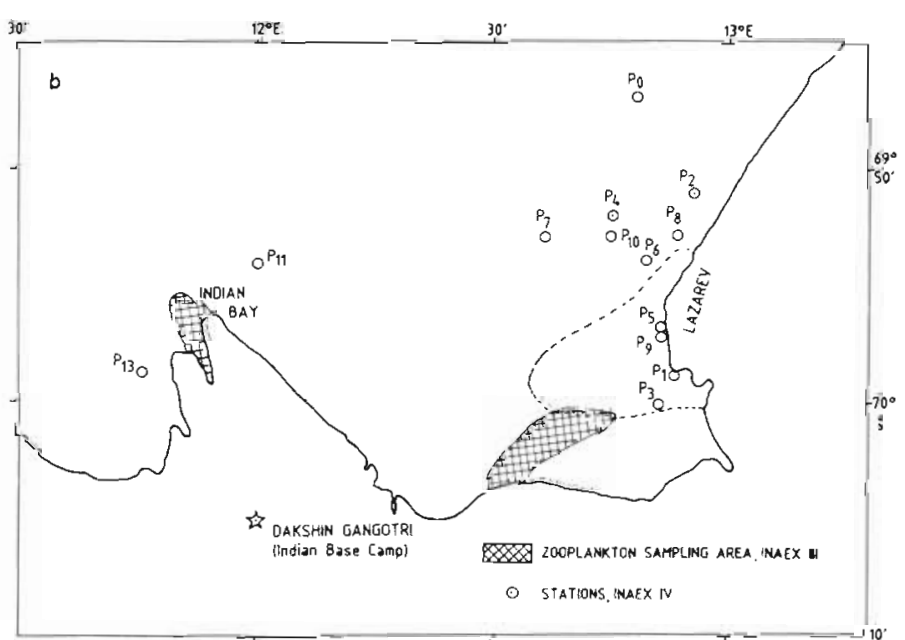

Fig. 1. Station positions during the 4 Antarctic Expeditions (INAEX I, III, IV \& V). Inset shows station positions during the 5th Indian. Antarctic Expedition. (b) Station positions in the coastal ice region during January-February 1984 and 1985 
IV), water samples were collected from 3 to 5 depths of the euphotic water column using Niskin bottles, and analysed along with nitrate, phosphate, silicate, dissolved oxygen and salinity using standard procedures as outlined by Grasshoff (1976). Chlorophyll a was measured fluorometrically (Strickland \& Parsons 1972) using a Turner Designs Fluorometer. ${ }^{14} \mathrm{C}$ assimilation experiments were carried out according to Strickland \& Parsons (1972). Water samples (125 ml) containing $5 \mu \mathrm{Ci}$ labelled carbon were incubated on board for $24 \mathrm{~h}$ and filtered through $0.45 \mu \mathrm{m}$ millipore filters. The incorporated carbon was measured by liquid scintillation counting, using a Packard Instrument Company Liquid Scintillation Counter. Zooplankton sampling during INAEX I was carried out by vertical hauls from $1000 \mathrm{~m}$ depth to the surface using the Indian Ocean Standard Net (IOSN, mesh size $0.3 \mathrm{~mm}$; Currie 1963). A bongo net of $60 \mathrm{~cm}$ mouth diameter and mesh size $0.4 \mathrm{~mm}$ was used from $150 \mathrm{~m}$ depth to the surface during INAEX III and from $200 \mathrm{~m}$ depth to the surface for INAEX IV sampling. Horizontal surface tows were made during INAEX V (1986) using a Heron Tranter Net (mouth area $0.25 \mathrm{~m}^{2}$, mesh size $0.3 \mathrm{~mm}$ ) at a minimum tow- ing speed of 1.5 knots. Biomass was determined in wet volume by the method of displacement.

Data collection was based on the availability of shiptime and hence consistency in sampling periods could not be maintained during the different expeditions from 1982 to 1986

\section{RESULTS AND DISCUSSION}

Different frontal zones, along the western section (11 to $53^{\circ} \mathrm{E}$ longitude) of the Southern Indian Ocean, from $30^{\circ} \mathrm{S}$ latitude to the Antarctic continent, were clearly identified by the contours of salinity, potential temperature, potential density and nutrients (INAEX III 1983-84; Fig. 2). The isolines of potential temperature $(\theta)$ and salinity indicate the formation of a strong Subtropical Convergence (STC) zone between Stns 10 and 11 (42 to $38^{\circ} \mathrm{S}$ ) and the Antarctic Convergence ( $\mathrm{AC}$ also known as Polar Front) zone between Stns 8 and 9 (53 to $46^{\circ} \mathrm{S}$ ). The classical way of identifying these convergence zones is from the rapid change in sea surface temperature from more than $15^{\circ} \mathrm{C}$ to less than $5^{\circ} \mathrm{C}$ between the latitudes of about 40 and $50^{\circ} \mathrm{S}$ (Wyrtki
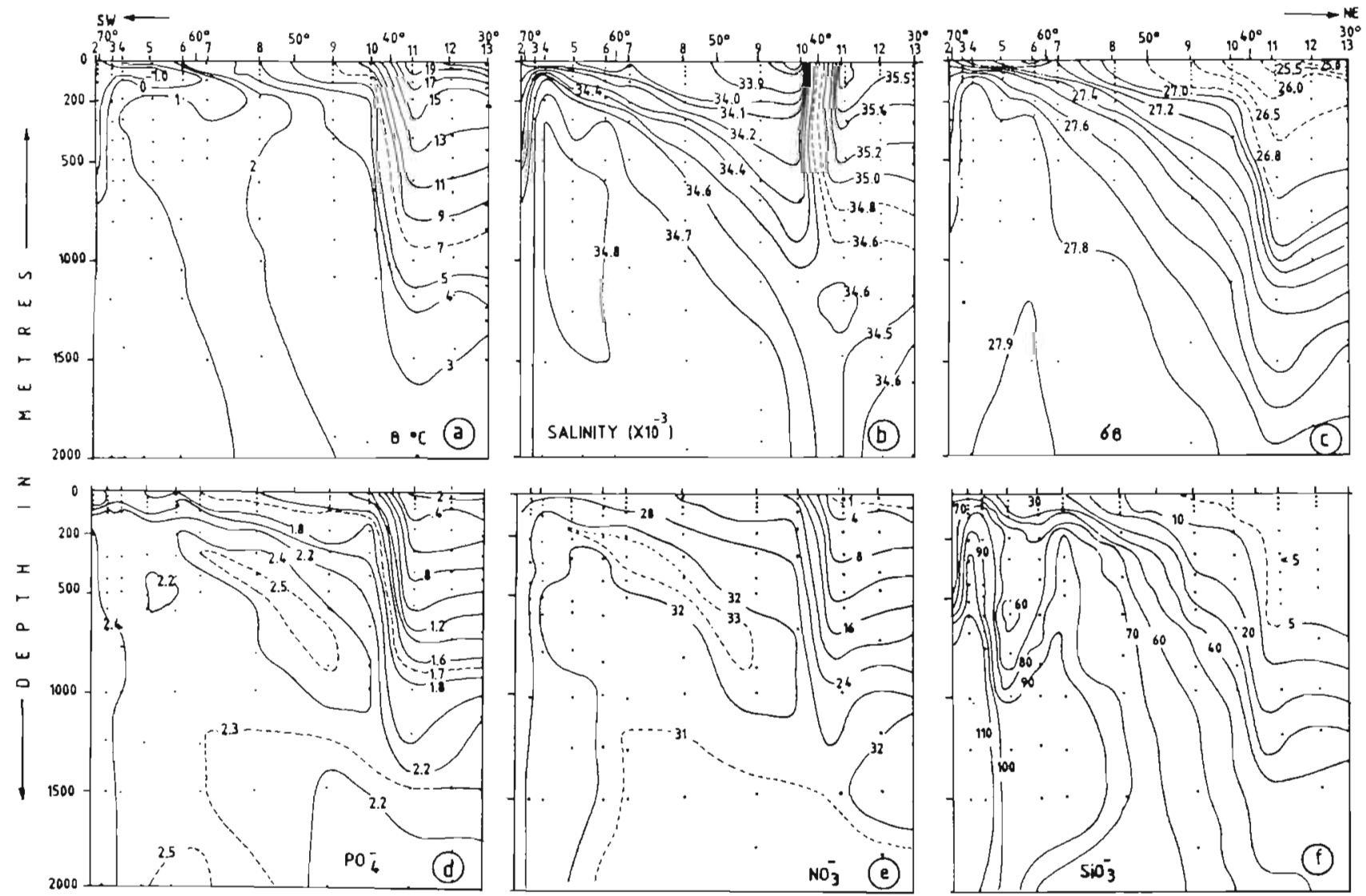

Fig. 2. Contours of (a) potential temperature $\left(\theta^{\circ} \mathrm{C}\right)$ (b) salinity $\left(\times 10^{-3}\right)$ (c) sigma- $\theta$ (d) phosphate $\left(\mathrm{PO}_{4} ; \mu \mathrm{M}\right)(\mathrm{e})$ nitrate $\left(\mathrm{NO} \mathrm{O}_{3} \mu \mathrm{M}\right)$ and (f) silicate $\left(\mathrm{SiO}_{3} ; \mu \mathrm{M}\right)$ in the study area (INAEX III) 
1973). From the INAEX I observations the STC zone was identified between 45 and $41^{\circ} \mathrm{S}$ (Rama Raju \& Somayajulu 1983). Fig. 2 shows a strong gradient of both temperature and salinity in the STC zone characteristic of a thermohaline front. At the Polar Front, only a temperature gradient was prominent thereby characterising it as a typical thermal front. In the STC zone from Stn 11 towards Stn 10 in the south, the salinity of Indian Ocean Central Water (IOCW) decreased by $1.9 \times 10^{-3}$ and temperature decreased by $10^{\circ} \mathrm{C}$ while $\mathrm{NO}_{3}, \mathrm{PO}_{4}$ and $\mathrm{SiO}_{3}$ increased by 17,7 and 2 -folds respectively in the upper $100 \mathrm{~m}$ (Fig. 3)

At the $\mathrm{AC}$ surface waters sink giving rise to the formation of the AIW with salinity of $34.6 \times 10^{-3}$ and $\theta$ of $4^{\circ} \mathrm{C}$ (Deacon 1982). Gamberoni et al. (1982) reported that the transition zone separating the $\mathrm{AC}$ and the STC lies between 43 and $46^{\circ} \mathrm{S}$ in the Kerguelen region (60 to $75^{\circ} \mathrm{E}$ ) and between 41 and $43^{\circ} \mathrm{S}$ in the Crozet region $\left(50^{\circ} \mathrm{E}\right.$ ). Deacon (1983) observed a gradual sinking of the Antarctic temperature minimum below $200 \mathrm{~m}$ between latitudes 49 and $48^{\circ} \mathrm{S}$ which corresponds to the $\mathrm{AC}$ in the Kerguelen/Crozet region. It is difficult to demarcate the precise location of the STC and AC from the present set of observa- tions as the distances between the stations were too great. However our results are in agreement with those of Deacon (1983).

At Stn $4\left(67^{\circ} \mathrm{S}\right)$, a peak in the salinity and temperature isolines is seen, where high salinity water from subsurface and deep layers is transported towards the surface. These waters show the characteristics of upwelled waters and it is possible that the zone of divergence lies between Stns 4 and 5. INAEX I observations showed the divergence to occur at around $63^{\circ} \mathrm{S}$ (Rama Raju \& Somayajulu 1983). Lutjeharms et al. (1985) reported the divergence region to be at around $65^{\circ} \mathrm{S}$. Wyrtki (1960), while working on frontal systems in Antarctica, showed that the position of divergence and convergence strongly depends on changing wind conditions. From these observations it could be concluded that there is considerable variation in the position of the Antarctic Divergence $(A D)$ at around $21^{\circ} \mathrm{E}$ longitude. The upward advected deep water near divergence mixes with low salinity and low temperature Antarctic Surface Water (ASW) resulting in an increase in the latter's density. From Stn 3 towards the continental margin at $70^{\circ} \mathrm{S}$ (Stn 2), the contours of temperature and salinity show a deepening trend. This

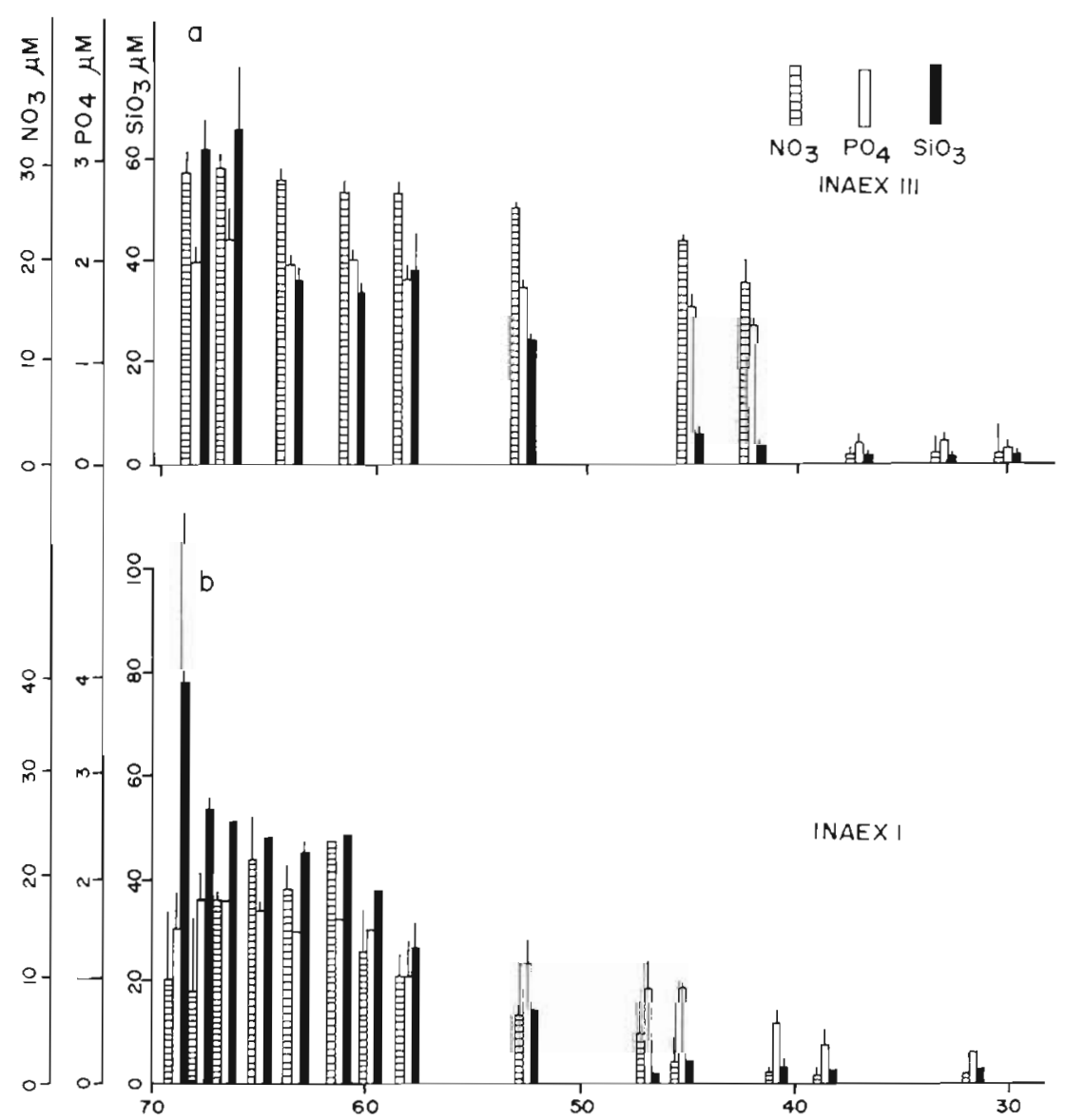

Fiq. 3. Latitudinal distribution of nutrients from 70 to $30^{\circ} \mathrm{S}$ in surface waters up to $100 \mathrm{~m}$ depth dunng (a) INAEX I (January-February 1982), (b) INAEX III (February to March 1984) 
shows that cold waters sinking along the continental slope could contribute to the Antarctic Bottom Water (AABW).

The cold ASW from Stns 5,6 and 7, with low salinity below $34 \times 10^{-3}$, flows northwards under the influence of the prevailing west winds and mixes with the warmer waters near the Antarctic Polar Front. In the Antarctic Convergence Zone (Stns 8 and 9) the sinking of low salinity surface water occurs. This water further spreads northwards to the subsurface layers giving rise to AIW. Nitrate and phosphate isopleths (Fig. 2) show similar features to potential temperature isolines and isohalines, indicating that physical mixing processes rather than biological activities are responsible for the changes in nutrient concentrations in this region. However, the behaviour of silicate seems to be rather different (Fig. 3). This could possibly be due to differences in the phytoplankton uptake and regeneration processes of $\mathrm{Si}$ as compared to $\mathrm{NO}_{3}$ and $\mathrm{PO}_{4}$ (Jacques 1983, Ronner et al. 1983, Koike et al. 1986, Sommer 1986).

The mixing processes between the different watermasses and the formation of the discontinuity layers can be examined with the help of potential temperature $(\theta)$ /salinity plots (Fig. 4; Broecker et al. 1976). The marked deviation in the slope for Stns 11, 12 and 13 north of the STC and the linear portion of the $\theta$ salinity plot for potential temperatures from 15 to $4.5^{\circ} \mathrm{C}$ could be due to mixing of the IOCW with AIW. The slope of $\theta$-salinity for stations south of STC deviates significantly, especially for stations in the Subantarctic and Divergence regions where the 2 discontinuities occur, producing a shape that could be described as a 'scorpion-tail' in the $\theta$-salinity plot. The

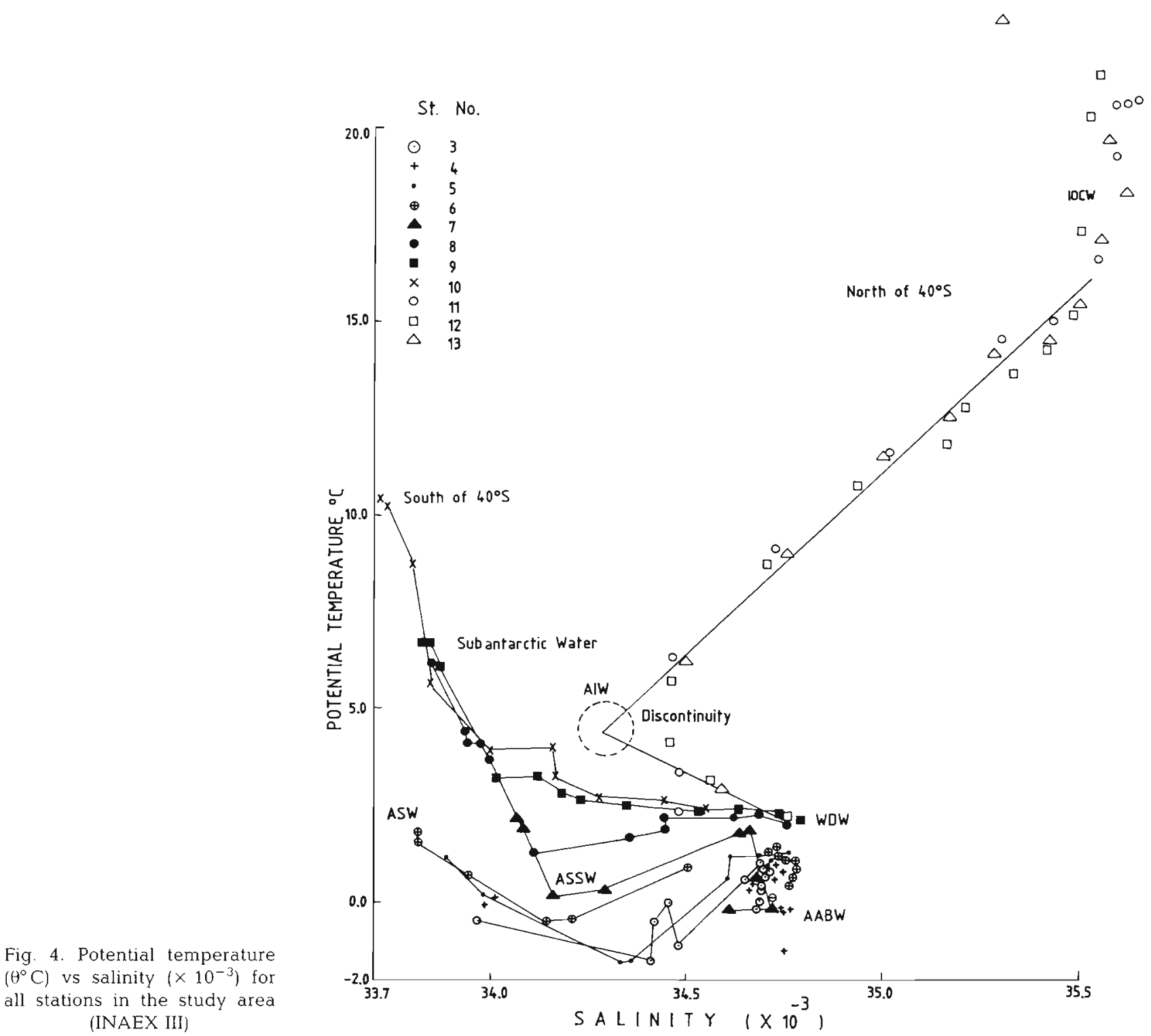


upper discontinuity is formed by the mixing of ASW and Subsurface Water (ASSW) and the lower discontinuity due to the simple mixing of the 2 water masses, the WDW and AABW. Further confirmation of the mixing processes by different watermasses was obtained by the method of Alvarez-Borrego et al. (1975). For this purpose oxygen residual values were plotted against potential temperature. The different watermasses were identified by the linear regression fit of the points, shown in Fig. 5. The various water masses and their mixing processes in the Convergence and Divergence zones described above could be represented in the form of a schematic diagram shown in Fig. 6. The intense physical mixing of the different water masses may have a pronounced influence on the distribution of nutrients and productivity in the ASW. This can be seen in the data from the INAEX I, III, IV and $V$ cruises.

\section{Coastal shelf edge zone}

Temperatures recorded in the upper $100 \mathrm{~m}$ of the water column during a 2 mo period, between $11^{\circ} 43^{\prime}$ and $12^{\circ} 55^{\prime} \mathrm{E}$ longitude (January and February 1985 ; INAEX IV; Fig. 1b) generally remained below $0.5^{\circ} \mathrm{C}$ (Table 1). From Fig. 7 it can be seen that the isotherms run vertically for most of the period. Surface salinity remained low indicating the effect of melting ice. The variation in density follows changes in salinity (Fig. 7). Table 1 shows that urea and ammonia were low while nitrate, phosphate and silicate were available in suffi-

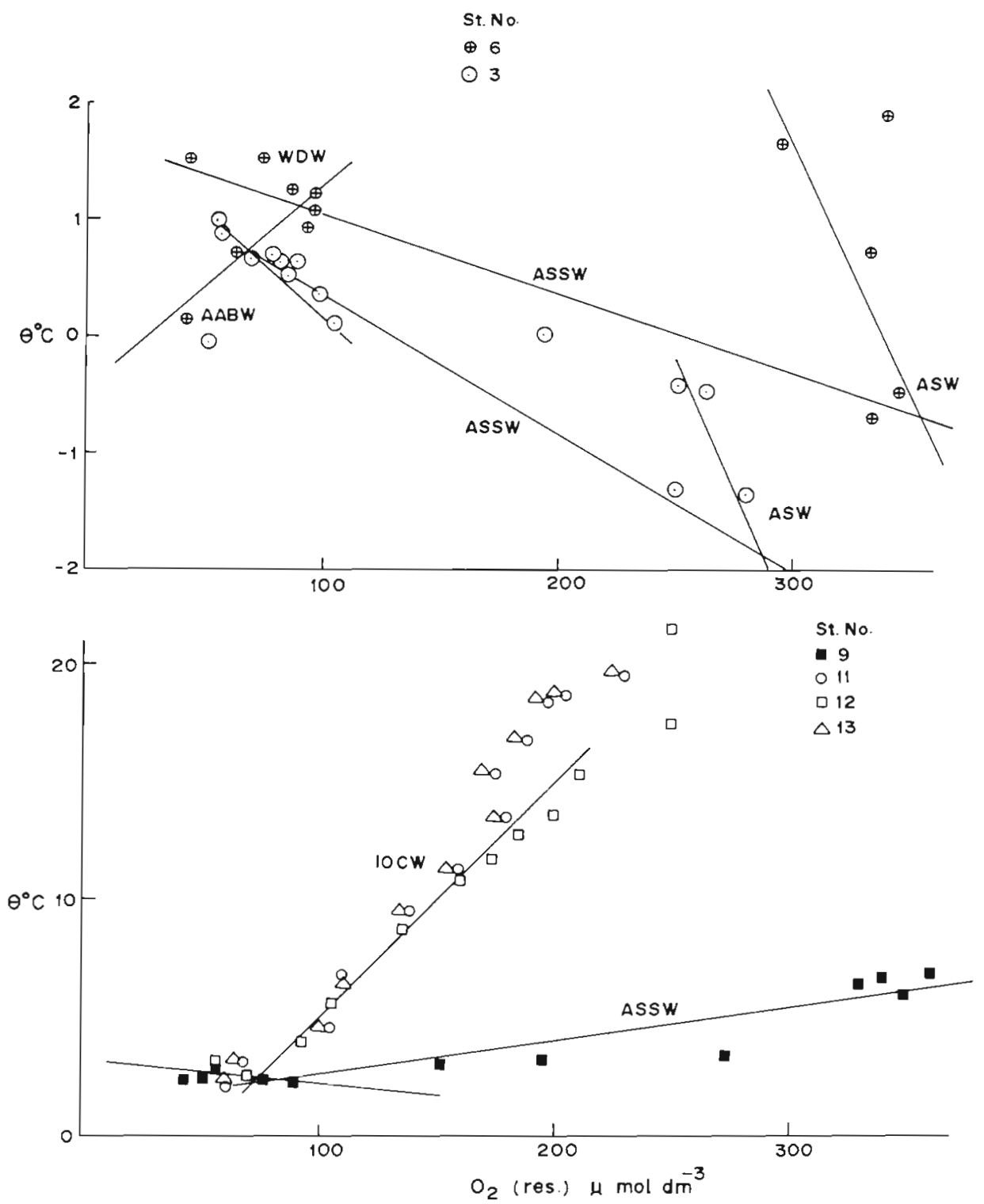

Fig. 5. Oxygen residual $1 \mathrm{O}_{2}$ res.) vs potential temperature (A) plot for selected stations (INAEX III) 


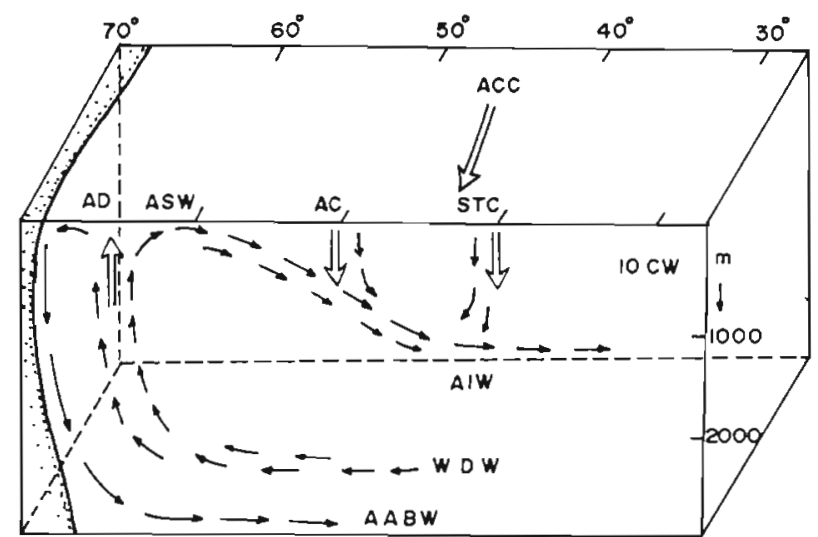

Fig. 6. Schematic diagram showing the distribution of various watermasses and the mixing processes. AC: Antarctic Convergence; $\mathrm{AD}$ : Antarctic Divergence; $\mathrm{AABW}$ : Antarctic Bottom Water; ACC: Antarctic Circumpolar Current; AIW: Antarctic Intermediate Water; ASW: Antarctic Surface Water: IOCW: Indian Ocean Central Water; STC: Subtropical Convergence; WDW: Warm Deep Water

ciently high concentrations (Fig. 8). Surface chlorophyll $a$ and primary productivity during January-February 1985 varied from 0.45 to $4.03 \mathrm{mg} \mathrm{m}^{-3}$ and from 0.4 to $3.33 \mathrm{mg} \mathrm{C} \mathrm{m}^{-3} \mathrm{~h}^{-1}$ respectively (Table 1 ). In the euphotic column daily production ranged from 0.3 to $1.03 \mathrm{~g} \mathrm{C}$ $\mathrm{m}^{-2} \mathrm{~d}^{-1}$ and chlorophyll a from 21.1 to $85.5 \mathrm{mg} \mathrm{m}^{-2}$ (Table 2). Microscopic examination of $500 \mathrm{ml}$ of sedimented water samples showed the presence of diatoms such as Fragilaria, Rhizosolenia, Cosinodiscus, Navicula and Corethron species (Table 3). Total cell

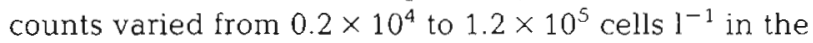
upper $50 \mathrm{~m}$. Mean zooplankton biomass (horizontal tow) was $365 \mathrm{ml} 1000 \mathrm{~m}^{-3}$ of water (Table 1). Krill formed a considerable fraction of zooplankton biomass. The high standard deviation values, i.e. $58 \%$ about the mean, suggest that the fluctuation in the day-to-day occurrence of zooplankton may be due to predation by higher animals such as seal and penguins. The 1984 summer observation (INAEX III) showed the mean values of chlorophyll and primary productivity (PP) in the surface waters to be $1.18 \mathrm{mg} \mathrm{m}^{-3}$ and $1.05 \mathrm{mg} \mathrm{C}$ $\mathrm{m}^{-3} \mathrm{~h}^{-1}$ respectively (Table 1 ). In the euphotic column mean values were: chl, $35.45 \mathrm{mg} \mathrm{m}^{-2}$; PP, $0.75 \mathrm{~g} \mathrm{C}$ $\mathrm{m}^{-2} \mathrm{~d}^{-1}$ (Table 2). Average column chl a values during 1985 were higher than those in 1984 (Table 2). But Student's t-test showed no significant difference in productivity and biomass values between these 2 summers. Day-to-day variation was marked with the occurrence of peaks of chlorophyll and PP at short intervals. The chlorophyll peaks could perhaps be related to the occurrence of Fragilaria spp. (Tables 3 and 4). The assimilation ratio during both summers remained low with a maximum value of $3.62 \mathrm{mg} \mathrm{C}$ (mg chl) $)^{-1} \mathrm{~h}^{-1}$ (Table 2 ).

Mean zooplankton biomass in 1984 was $61.3 \mathrm{ml}$ $1000 \mathrm{~m}^{-3}$ (Mathew \& Vincent 1986a). An interesting feature to be noted during the 2 successive summers is that the algal peak during early and mid January was followed by a zooplankton increase towards the end of January and beginning of February. It appears therefore that the addition of phytoplankton seeded from ice algae helps in a steady build-up of zooplankton and krill biomass in the ice edge ecosystem (El-Sayed \& Taguchi 1981, McConville et al. 1985).

\section{Antarctic oceanic region south of $67^{\circ} \mathrm{S}$}

While offshore temperature variations in 1985 (INAEX IV) were similar to those of the coastal waters, salinity values were slightly higher near the Diver-

Table 1. Maximum, minimum and mean values of different parameters at the coastal ice edge and at oceanic stations in the region south of $67^{\circ} \mathrm{S}$ latitude (INAEX IV)

\begin{tabular}{|c|c|c|c|c|c|c|c|c|c|c|}
\hline \multirow[t]{2}{*}{ Parameter } & \multicolumn{5}{|c|}{ Coastal region } & \multicolumn{5}{|c|}{ Oceanic region } \\
\hline & Min. & Max. & Mean & $\mathrm{SD}$ & $\mathrm{n}$ & Min. & Max. & Mean & $\mathrm{SD}$ & $\mathrm{n}$ \\
\hline Temperature $\left({ }^{\circ} \mathrm{C}\right)$ & -2.0 & 1.0 & -0.43 & \pm 0.69 & 55 & -2.0 & 0.5 & -0.3 & \pm 0.86 & 11 \\
\hline Salinity $\left(\times 10^{-3}\right)$ & 33.17 & 34.45 & 33.81 & \pm 0.37 & 55 & 33.87 & 34.81 & 34.40 & \pm 0.32 & 11 \\
\hline Sigma-t & 26.66 & 27.75 & 27.18 & \pm 0.29 & 55 & 27.17 & 28.52 & 27.68 & \pm 0.26 & 11 \\
\hline Urea $(\mu \mathrm{M})$ & 0 & 2.37 & 0.59 & \pm 0.39 & 55 & 0.2 & 1.30 & 0.96 & \pm 0.78 & 11 \\
\hline Ammonia $(\mu \mathrm{M})$ & 0.05 & 2.21 & 0.54 & \pm 0.44 & 55 & 0.14 & 1.36 & 0.69 & \pm 0.44 & 11 \\
\hline Nitrate $(\mu \mathrm{M})$ & 7.82 & 23.1 & 15.12 & \pm 4.05 & 55 & 22.55 & 29.50 & 25.80 & \pm 2.40 & 11 \\
\hline Nitrite (uM) & 0.02 & 0.4 & 0.16 & \pm 0.13 & 24 & 0.01 & 0.15 & 0.07 & \pm 0.05 & 8 \\
\hline Phosphate $(\mu \mathrm{M})$ & 0.60 & 3.0 & 1.53 & \pm 0.53 & 55 & 1.71 & 2.35 & 1.95 & \pm 0.17 & 11 \\
\hline Silicate $(\mu \mathrm{M})$ & 26.50 & 54.1 & 34.91 & \pm 6.22 & 55 & 52.0 & 61.9 & 55.76 & \pm 3.47 & 11 \\
\hline Surface chl $\left(\mathrm{mg} \mathrm{m}^{-3}\right)$ & 0.45 & 4.03 & 1.60 & \pm 1.03 & 10 & 0.19 & 0.43 & 0.3 & \pm 0.09 & 4 \\
\hline $\begin{array}{l}\text { Surface primary productivity } \\
\left(\mathrm{mgC} \mathrm{m}^{-2} \mathrm{~h}^{-1}\right)\end{array}$ & 0.4 & 3.33 & 1.61 & \pm 0.96 & 10 & 0.21 & 0.38 & 0.30 & \pm 0.06 & 4 \\
\hline $\begin{array}{l}\text { Zooplankton biomass } \\
\text { (ml } 1000 \mathrm{~m}^{-3} \text { ) }\end{array}$ & 108 & 720 & 365 & \pm 206 & 10 & 160 & 268 & 214 & \pm 49 & 5 \\
\hline
\end{tabular}




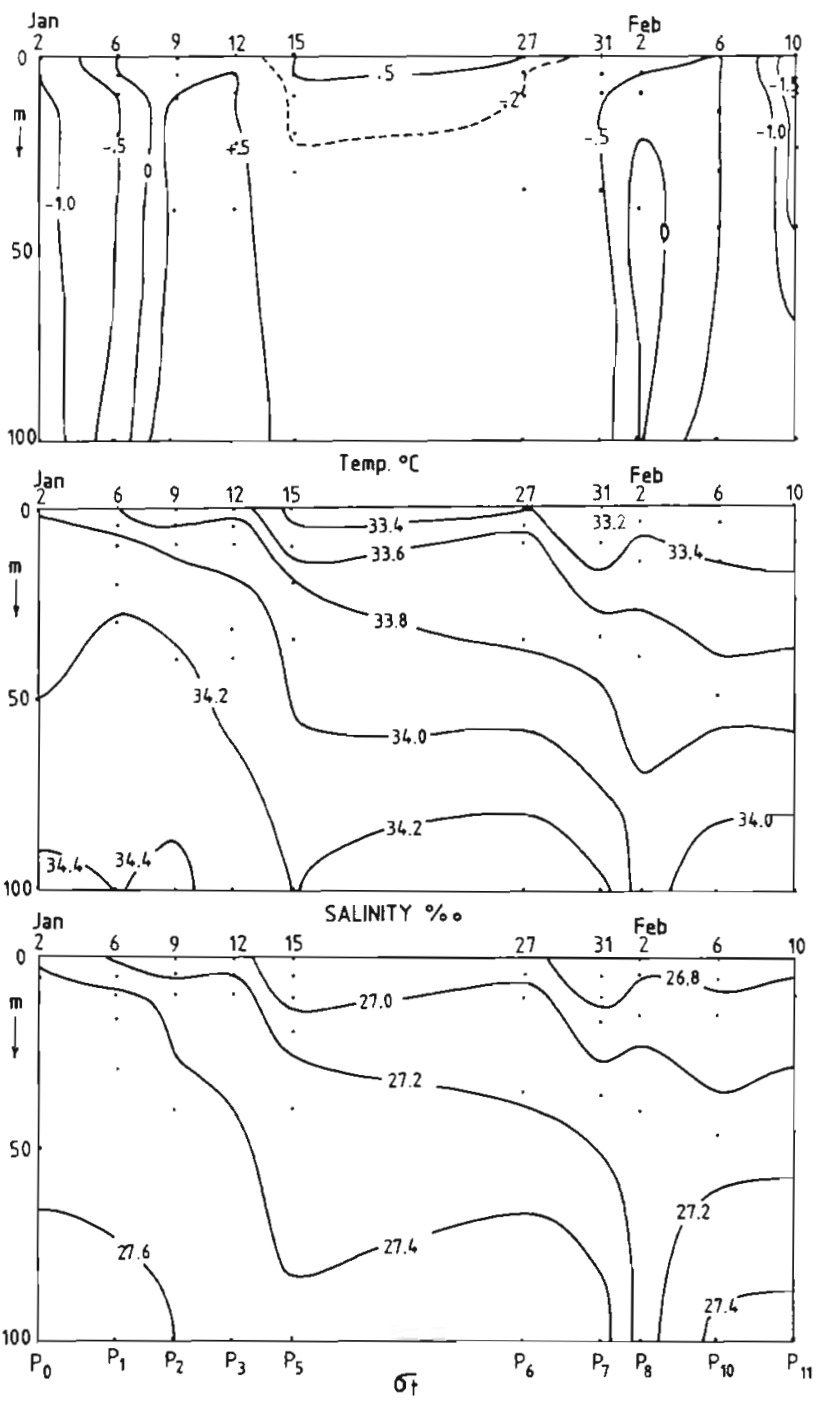

Fig. 7. Contours of temperature, salinity and sigma-t in the coastal ice edge region during austral summer (JanuaryFebruary 1985; INAEX IV)

gence zone (Fig. 1a; Table 1). Nutrient distribution, especially nitrate and silicate, exhibited a marked boundary between the high values in this oceanic region (mean $\mathrm{NO}_{3}-\mathrm{N}, 25.8 \pm 2.4 \mu \mathrm{M} ; \mathrm{PO}_{4}-\mathrm{P}, 1.95 \pm$ $\left.0.17 \mu \mathrm{M} ; \mathrm{SiO}_{3}-\mathrm{Si}, 55.8 \pm 3.5 \mu \mathrm{M}\right)$ and comparatively lower concentrations at the ice edge zone (Table 1). On the other hand, surface chlorophyll and PP values in the oceanic region (mean values: chl, $0.3 \mathrm{mg} \mathrm{m}^{-3}$; and PP, $0.3 \mathrm{mg} \mathrm{C} \mathrm{m}^{-3} \mathrm{~h}^{-1}$ ) were almost 5-fold lower than those in the coastal waters (Table $1 ;$ Figs. $8 \mathrm{~b}$ and $9 c)$. In the euphotic column also, chlorophyl and PP were much lower in the offshore waters. Assimilation numbers, however remained similar in coastal and offshore waters. The mean zooplankton biomass of $365.3 \mathrm{ml} 1000 \mathrm{~m}^{-3}$ in the coastal water was 1.7 times higher than in offshore waters with the percentage distribution of krill at about $25 \%$ in both regions. Results suggest that the waters at the continental ice edge were more productive than the offshore waters in 1985 (Fogg 1977, El-Sayed \& Taguchi 1981, ElSayed et al. 1983). While chlorophyli and PP in 1984 behaved in a similar manner as in 1985, zooplankton were reported to have shown an increasing trend from 69 to $67^{\circ} \mathrm{S}$ (Mathew 1986). Differences in the sampling periods of the 2 cruises could perhaps give rise to the observed pattern of zooplankton distribution. Sampling for INAEX IV was made in early summer 23 to 27 December 1984); that of INAEX III was in late summer (2 to 5 March 1984). While during early summer the ice algae contribute to the biomass production, reforming of plate ice during late summer (towards the end of February) may result in a shift of zooplanktonic organisms towards the north.

\section{Other oceanic regions north of $67^{\circ} \mathrm{S}$}

Fig. 9 shows the distribution of chlorophyll and PP in the Antarctic, Subantarctic and Subtropical regions extending from $69^{\circ} \mathrm{S}$ to beyond STC for 1982 (Fig. 9a), and zooplankton biomass for 1982 to 1985 summer seasons (Fig. 9a to d). In the oceanic region between 67 and $30^{\circ} \mathrm{S}$, the highest surface chlorophyll value encountered was $0.7 \mathrm{mg} \mathrm{m}^{-3}$ at Stn $11\left(58^{\circ} 16^{\prime} \mathrm{S}\right)$. The other stations along the track showed low chlorophyll and PP in surface waters. The euphotic water column also showed high chlorophyll a of $64.35 \mathrm{mg} \mathrm{m}^{-2}$ at Stn 11 (Table 5). Elevated chlorophyll a values were seen at a few more locations in the Antarctic region south of Stn 11. In the Subtropical zone the highest chlorophyll a encountered was $23.6 \mathrm{mg} \mathrm{m}^{-2}$ at Stn 17 $\left(32^{\circ} \mathrm{S}\right)$. Like chlorophyll a the PP values in the water column showed an increase at $\operatorname{Stn} 11$. However the highest PP value of $0.7 \mathrm{~g} \mathrm{C} \mathrm{m}^{-2} \mathrm{~d}^{-1}$ was at $\operatorname{Stn} 4$ $\left(68^{\circ} 48^{\prime} \mathrm{S}\right)$ while at the other stations it remained low. Assimilation numbers in these oceanic stations remained low fluctuating between 0.26 and $1.2 \mathrm{mg} \mathrm{C}$ (mg chl) $)^{-1} \mathrm{~h}^{-1}$ (Table 5).

Zooplankton biomass, especially that of krull, during INAEX I (1982) was richest in the Antarctic region between 62 and $58^{\circ} \mathrm{S}$, with a miximum of $624 \mathrm{ml}$ $1000 \mathrm{~m}^{-3}$ (Fig. 9). This region lies between the Antarctic Divergence and Convergence and surface waters during this season were characterized by somewhat higher temperatures (mean $0.86^{\circ} \mathrm{C}$ ) than in more southerly latitudes (mean $-0.96^{\circ} \mathrm{C}$ ). This may perhaps favour proliferation of zooplankton and krill.

Vertical hauls in 1985 (INAEX IV) showed a highest zooplankton biomass of $565 \mathrm{ml} 1000 \mathrm{~m}^{-3}$ around $58^{\circ} \mathrm{S}$. However, surface tows during March 1986 (INAEX V) indicated that the maximum zooplankton of $322 \mathrm{ml}$ 

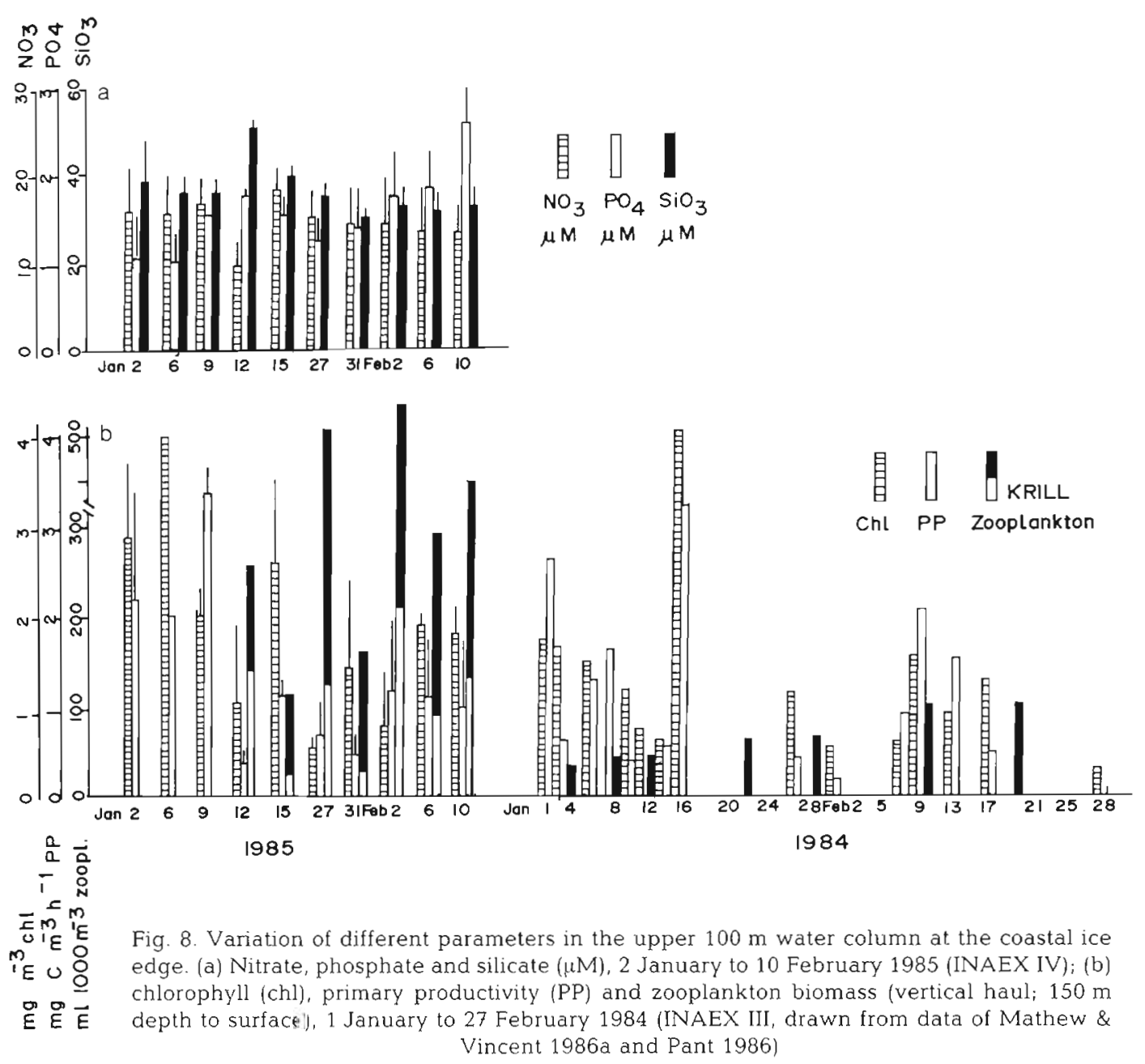

$1000 \mathrm{~m}^{-3}$ was centered around $53^{\circ} \mathrm{S}$ latitude. The close grid vertical haul by bongo net in 1984 (INAEX III; Fig. 9) showed that the highest aggregation of zooplankton (maximum $329 \mathrm{ml} 1000 \mathrm{~m}^{-3}$ water) was located around $61^{\circ} \mathrm{S}$. The region south of this latitude up to the ice edge was also rich while a minor peak occurred to the north, close to $\mathrm{AC}\left(46^{\circ} \mathrm{S}\right)$.

Results from the 4 summers show that zooplankton biomasses at particular locations are not consistent among years. These interannual discrepancies were expected. They can be assigned to differences in the net structure used and in the methods of zooplankton collection employed. Nonetheless, some regions stand out as consistently more productive than others. To study the variations on the longitudinal scale, the zooplankton data collected during each of the 4 cruises, and also the chlorophyll $a$ and PP values of INAEX I, were grouped by $5^{\circ}$ latitudes. Table 6 shows variations in productivity and zooplankton stocks from Antarctic, Subantarctic and Subtropical regions. Antarctic waters lying south of $\mathrm{AC}\left(46^{\circ} \mathrm{S}\right)$ were richer than Subantarctic waters to the north of
AC, while Subtropical waters showed still lower values.

Efifect of $\mathrm{AC}$ on the occurrence of phytoplankton and zooplankton

Previous investigations have reported low values of $\mathrm{PP}$ and chlorophyll coincident with the position of $\mathrm{AC}$ (El-Sayed \& Mandelli 1965, El-Sayed 1967). This has been attributed to the instability of the water column due to deep-reaching turbulence, which prevents phytoplankton from remaining in the optical light zone long enough for phytoplankton production (El-Sayed \& Mandelli 1965, Hasle 1969, El-Sayed 1987), Our observations during INAEX I also showed low values of chlorophyll a and PP in the AC zone (53 to $46^{\circ} \mathrm{S}$ ). Values increased immediately south of this latitude. In contrast to these observations, some investigations have reported marked increase in PP and chlorophyll biomass near AC (Allanson et al. 1981, El-Sayed \& Weber 1982, Yamaguchi \& Shibata 1982). Although our 
Table 2. Chlorophyll (Chl; $\mathrm{mg} \mathrm{m}^{-2}$ ), primary productivity ( $\mathrm{PP} ; \mathrm{gC} \mathrm{m}^{-2} \mathrm{~d}^{-1}$ ) in the water column and assimilation number (AN; mg $\left.\mathrm{C}\left[\mathrm{mg} \mathrm{chl}^{-1}\right] \mathrm{h}^{-1}\right)$ during January and February 1984 and 1985

\begin{tabular}{|c|c|c|c|c|c|c|c|}
\hline $\begin{array}{l}1984 \\
\text { Sampling } \\
\text { date }\end{array}$ & PP & Chl & AN & $\begin{array}{c}1985 \\
\text { Sampling } \\
\text { date }\end{array}$ & PP & Chl & AN \\
\hline January & & & & January & & & \\
\hline 1 & 1.85 & 51.6 & 1.49 & - & - & - & - \\
\hline 2 & 0.4 & 49.0 & 0.34 & 2 & 1.02 & 75.30 & 0.56 \\
\hline 5 & 0.94 & 43.5 & 0.9 & 6 & $2.04^{a}$ & $4.03^{a}$ & $0.51^{\mathrm{d}}$ \\
\hline 7 & 1.13 & 13.0 & 3.62 & - & - & - & - \\
\hline 9 & 0.26 & 34.4 & 0.31 & 9 & 0.66 & 16.62 & 1.65 \\
\hline 11 & 0.06 & 21.0 & 0.12 & 12 & 0.37 & 42.1 & 0.37 \\
\hline 13 & 0.36 & 19.0 & 0.79 & - & - & - & - \\
\hline 15 & 2.3 & 118.8 & 0.81 & 15 & 0.97 & 85.5 & 0.47 \\
\hline 27 & 0.31 & 32.5 & 0.4 & 27 & 0.48 & 21.1 & 0.95 \\
\hline 31 & 0.11 & 15.0 & 0.31 & 31 & 0.3 & 68.42 & 0.18 \\
\hline February & & & & February & & & \\
\hline 2 & - & - & - & 2 & 0.96 & 21.9 & 1.83 \\
\hline 6 & 0.66 & 17.0 & 1.62 & 6 & 1.03 & 76.0 & 0.56 \\
\hline 8 & 1.48 & 45.2 & 1.36 & 10 & 0.94 & 82.2 & 0.48 \\
\hline 12 & 1.1 & 26.1 & 1.76 & - & - & - & - \\
\hline 16 & 0.34 & 37.8 & 0.37 & - & - & - & - \\
\hline 29 & 0.01 & 7.9 & 0.05 & - & - & - & - \\
\hline Mean & 0.75 & 35.45 & 0.95 & & 0.75 & 54.35 & 0.76 \\
\hline $\mathrm{SD}$ & \pm 0.67 & \pm 26.0 & \pm 0.9 & & \pm 0.28 & \pm 27.05 & \pm 0.53 \\
\hline
\end{tabular}

Table 3. Cell counts of major species in euphotic depth (January-February 1985), INAEX IV

\begin{tabular}{|c|c|c|c|c|c|c|}
\hline \multirow{2}{*}{$\begin{array}{l}\text { Date } \\
(1985)\end{array}$} & \multirow{2}{*}{$\begin{array}{c}\text { Depth } \\
(\mathrm{m})\end{array}$} & \multirow{2}{*}{$\begin{array}{c}\log _{10} \\
\text { cells } L^{-1}\end{array}$} & \multicolumn{4}{|c|}{ Percent composition } \\
\hline & & & Fragilaria sp. & Rhyzosolenia sp. & Cosinodiscus sp. & Remainder \\
\hline $6 \mathrm{Jan}$ & 0 & 5.0791 & 93 & NR & 4 & 3 \\
\hline \multirow[t]{4}{*}{$12 \mathrm{Jan}$} & 0 & 4.2787 & 71 & NR & 2 & 27 \\
\hline & 5 & 4.3617 & 55 & 11 & 6 & 28 \\
\hline & 10 & 4.5314 & 49 & 9 & 6 & 35 \\
\hline & 40 & 4.6127 & 77 & 6 & 5 & 11 \\
\hline \multirow{4}{*}{$27 \mathrm{Jan}$} & 0 & 3.6020 & 40 & NR & 10 & 50 \\
\hline & 5 & 3.3010 & 20 & NR & 40 & 40 \\
\hline & 10 & 3.9030 & 14 & NR & 4 & 82 \\
\hline & 35 & 4.0791 & 83 & 3 & 5 & 9 \\
\hline \multirow[t]{4}{*}{2 Feb } & 0 & 4.2552 & 36 & NR & 18 & 46 \\
\hline & 5 & 3.9912 & 67 & 10 & 5 & 17 \\
\hline & 15 & 4.1760 & 86 & 1 & 3 & 11 \\
\hline & 40 & 3.7558 & 86 & NR & 8 & 6 \\
\hline \multirow[t]{6}{*}{$10 \mathrm{Feb}$} & 0 & 4.2787 & 24 & 66 & 1 & 9 \\
\hline & 5 & 3.9912 & 25 & 59 & $N R$ & 16 \\
\hline & 10 & 4.1461 & 64 & 10 & NR & 26 \\
\hline & 25 & 4.0791 & 44 & 16 & 1 & 39 \\
\hline & 45 & 4.1.139 & 72 & 2 & 1 & 23 \\
\hline & 100 & 2.8450 & 30 & 20 & NR & 50 \\
\hline 27 Feb & 0 & 4.6394 & 78 & 7 & NR & 15 \\
\hline 28 Feb & 0 & 4.4313 & 76 & 1 & NR & 20 \\
\hline
\end{tabular}


Table 4. Cell counts and major species in euphotic depth (January-February 1984), INAEX III. (Source: Pant 1986)

\begin{tabular}{|c|c|c|c|c|c|c|}
\hline \multirow{2}{*}{$\begin{array}{l}\text { Date } \\
(1984)\end{array}$} & \multirow{2}{*}{$\begin{array}{l}\text { Depth } \\
(\mathrm{m})\end{array}$} & \multirow{2}{*}{$\begin{array}{l}\log _{10} \\
\text { cells } 1^{-1}\end{array}$} & \multicolumn{4}{|c|}{ Percent composition } \\
\hline & & & $\begin{array}{c}\text { Fragilaria } \\
\text { jslandia }\end{array}$ & Thalassiosira sp. & Navicula sp. & Remainder \\
\hline \multirow[t]{3}{*}{$1 \mathrm{Jan}$} & 0 & 3.4770 & 7 & 23 & 3 & 67 \\
\hline & 5 & 3.4770 & 47 & 23 & 9 & 21 \\
\hline & 35 & 3.7000 & 38 & 27 & 9 & 24 \\
\hline \multirow{3}{*}{2 Jan } & 0 & 4.7800 & 50 & 28 & 2 & 20 \\
\hline & 5 & 4.7000 & 72 & 7 & 15 & 6 \\
\hline & 30 & 3.0000 & NR & 36 & 9 & 55 \\
\hline \multirow[t]{3}{*}{$5 \mathrm{Jan}$} & 0 & 4.4100 & 82 & 7 & 14 & 4 \\
\hline & 5 & 3.6000 & 37 & 13 & 37 & 13 \\
\hline & 30 & 3.9000 & 69 & 27 & NR & 4 \\
\hline \multirow[t]{3}{*}{$7 \mathrm{Jan}$} & 0 & 3.4800 & NR & 21 & NR & 79 \\
\hline & 5 & 3.3000 & 6 & NR & 6 & NR \\
\hline & 30 & 3.6000 & 7 & 47 & 3 & 43 \\
\hline \multirow[t]{3}{*}{$9 \mathrm{Jan}$} & 0 & 4.5180 & 36 & 1 & 45 & 18 \\
\hline & 5 & 4.0400 & 72 & 4 & 7 & 20 \\
\hline & 30 & 4.2000 & 55 & NR & 13 & 32 \\
\hline \multirow[t]{3}{*}{$13 \mathrm{Jan}$} & 0 & 4.7600 & 87 & 3 & 4 & 6 \\
\hline & 5 & 4.1800 & 74 & 8 & 5 & 13 \\
\hline & 30 & 3.9500 & 57 & 21 & 1 & 21 \\
\hline \multirow[t]{3}{*}{$15 \mathrm{Jan}$} & 0 & 5.5200 & 92 & 6 & 1 & 1 \\
\hline & 5 & 5.2200 & 83 & 4 & 12 & 1 \\
\hline & 30 & 4.5300 & 98 & 1 & NR & 1 \\
\hline \multirow[t]{2}{*}{$27 \mathrm{Jan}$} & 0 & 3.9000 & 69 & 16 & $N R$ & 15 \\
\hline & 5 & 3.4100 & 58 & 38 & NR & 4 \\
\hline \multirow[t]{3}{*}{$31 \mathrm{Jan}$} & 0 & 4.0800 & 23 & 49 & 2 & 26 \\
\hline & 5 & 3.8400 & 10 & 33 & NR & 57 \\
\hline & 30 & 3.7000 & 4 & 31 & 4 & 61 \\
\hline \multirow[t]{3}{*}{16 Feb } & 0 & 3.3000 & 35 & 25 & 10 & 30 \\
\hline & 5 & 3.0000 & 46 & 8 & NR & 46 \\
\hline & 30 & 3.3000 & 32 & 32 & NR & 36 \\
\hline
\end{tabular}

observations on PP and chlorophyll near the Polar Front are not complete for all 4 summers, the zooplankton data (Fig. 9) shows that stocks of these organisms were more dominant in the Convergence zone than even at the ice edge, where chlorophyll and PP were high.

Figs. 2 and 7 show that the Antarctic waters in the euphotic zone are well mixed vertically. This suggests that the instability in the water column within the Polar Front should not have a pronounced effect on planktonic production as was suggested above. This will have to be explained by processes other than stability or instability of the water column.

\section{Standing crop and production in other Antarctic regions}

Information on PP and chlorophyll a in some of the extensively studied regions in Antarctic waters such as those in the south Atlantic, areas east and west of the
Antarctic Peninsula and those in the Indian Ocean have been summarised in Table 7 . The values show pronounced discrepancies in the productivity estimates reported by different investigators. Nevertheless these values agree with our observations that productivity in the oceanic region is lower than that in inshore waters. Also the regions south of $\mathrm{AC}$ are richer than Subantarctic and Subtropical waters.

Interestingly it can be noted that mean values of surface chlorophyll and PP for inshore waters in Antarctica in the present study were at least 4 times lower than those reported for the south Atlantic Ocean (El-Sayed 1967, Hayes et al. 1984). Similarly, productivity values in offshore oceanic waters south of $\mathrm{AC}$ were strikingly lower than even some of the least productive geographic regions of the Atlantic and Pacific Oceans listed in Table 7. However, if the different regions in the Indian sector of the Antarctic Ocean are considered then our mean column productivity value of $0.25 \mathrm{mg} \mathrm{C} \mathrm{m} \mathrm{m}^{-2} \mathrm{~d}^{-1}$ is much higher than those 

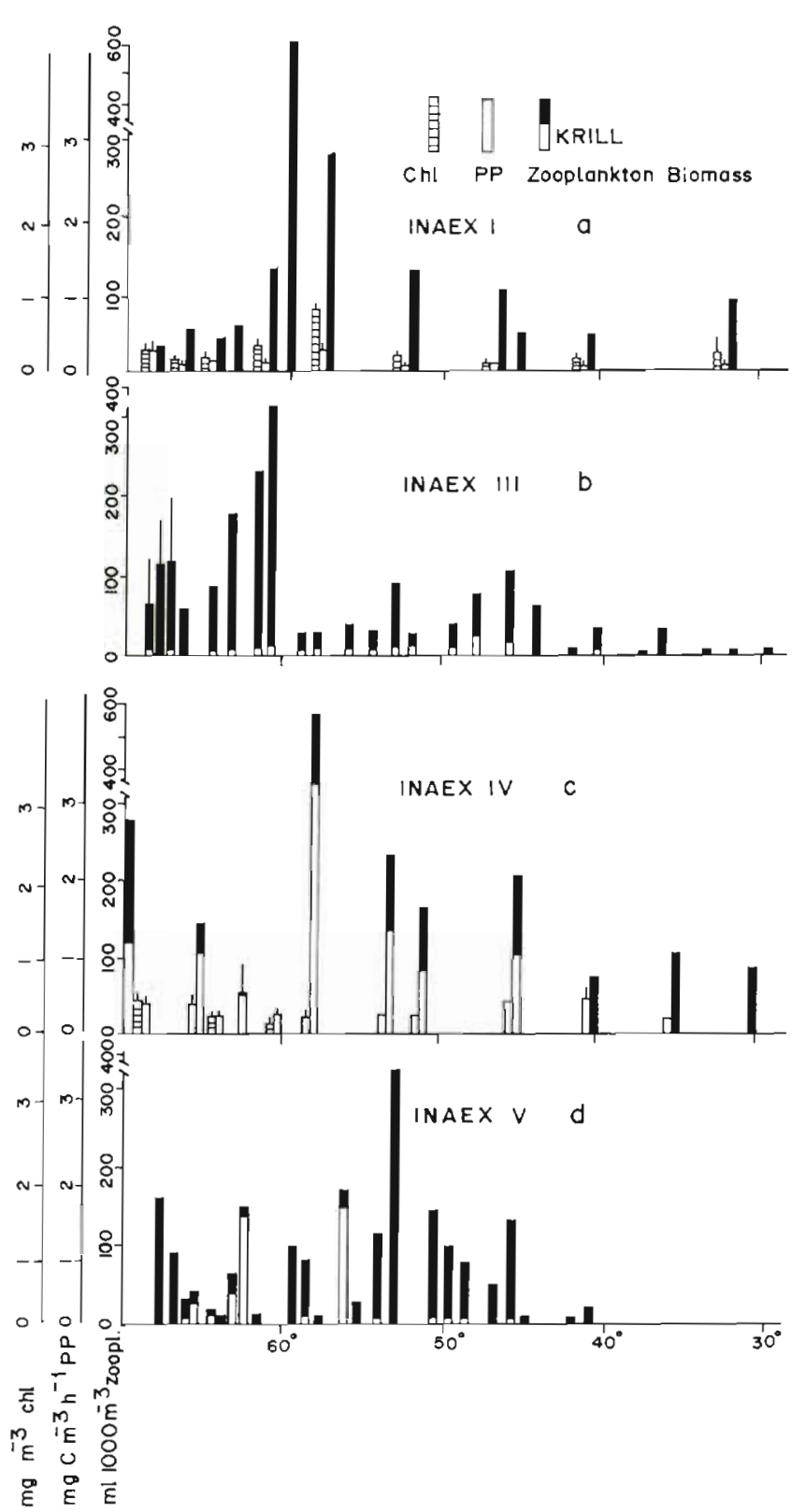

Fig. 9. (a) Chl, PP and zooplankton distribution (vertical haul $1000 \mathrm{~m}$ depth to surfacel from 70 to $30^{\circ} \mathrm{S}$ latitude during 19 January to 2 February 1982 (INAEX I). (b) Zooplankton distribution, Bongo net, oblique haul (150 $\mathrm{m}$ depth to surface), 2 to 18 March 1984 (INAEX III drawn from data of Mathew \& Vincent 1986b). (c) Zooplankton distribution, Bongo net (200 m depth to surface), 3 to 12 March 1985 (INAEX IV). (d) Zooplankton distribution, surface tow, H. T net, from 4 to 12 March 1986 (INAEX V)

reported by Saijo \& Kawashima (1964) for the sectors to the east and west.

Compilation of data on oceanic stations (Platt \& Subba Rao 1975) showed that the assimilation number varies from 1 to 10 . High assimilation numbers have been attributed to healthy log phase populations. Sev- eral other investigators have used assimilation number to differentiate nutrient-rich and-poor waters, the upwelling regions in tropical and temperate waters being associated with high values (Curl \& Small 1965, Subba Rao 1969. Thomas 1970, Platt \& Subba Rao 1975). In the present study the assimilation numbers were usually less than 2 . The profile of inorganic nutrients in Fig. 3a show that while $\mathrm{NO}_{3}$ and $\mathrm{PO}_{4}$ during 1984 (INAEX III) remain consistently high in surface waters in the entire region south of STC $\left(\mathrm{NO}_{3}\right.$ $>17 \mu \mathrm{m}$ and $\mathrm{PO}_{4}>1.2 \mu \mathrm{M}$ ), the Si values show more pronounced changes. The high silica values of more than $28 \mu \mathrm{M}$ are more often located to the south of $53^{\circ} \mathrm{S}$. Silica concentrations in the surface waters decreased to less than $6 \mu \mathrm{M}$ towards the north (Stn 9). Observations during early summer 1982 showed similar variation in nutrients with low silica values to the north of $53^{\circ} \mathrm{S}$ (Fig. 3b). These results, when compared with biological productivity, may give some indication of Si limitation by Antarctic diatoms. Jacques (1983) have reported half-saturation constants (KSi) of $12 \mu \mathrm{M}$ for Nitzschia turgidula and 12 to $22 \mu \mathrm{M}$ for the extremely silicified Nitzschia kergulensis. Sommer (1986) have shown KSi as high as $59.6 \mu \mathrm{M}$ for Corethron criophiliu and $89.4 \mu \mathrm{M}$ for $N$. kergulensis. Such high values sometimes exceed even the ambient $\mathrm{Si}$ concentration in surface Antarctic waters. Studies on nutrient distribution by Walsh (1971) and Allanson et al. (1981) have shown that silicates may be the most limiting nutrients for Antarctic diatom growth. However, Copin-Montegut \& Copin-Montegut (1978) encountered high concentration of particulate Si at the Polar Front and in the southern region. Also Kennett (1977) reported high rates of silicious biogenic sedimentation at Polar Fronts. These observations indicate that substantial primary productivity occurs in surface waters near the Polar Front which may not be affected by low levels of $\mathrm{Si}$.

Sommer (1986) showed that the affinity constant for $\mathrm{NO}_{3}$ was low as compared to $\mathrm{SiO}_{3}\left(\mathrm{KNO}_{3}=4.4 \mu \mathrm{M}\right.$ for Nitzschia cylindrus). Other workers have observed that Antarctic phytoplankton prefer reduced $N$ sources like $\mathrm{NH}_{4}$ and urea (Probyn \& Painting 1985, Koike et al. 1986). In the present study the concentrations of urea and ammonia were found to be high and varied from 0.14 to 2.31 and 0.2 to $2.03 \mu \mathrm{M}$ respectively Ammonia values were negatively correlated with phytoplankton biomass suggesting its biogenic uptake by phytoplankton (El-Sayed et al. 1983). Ronner et al. (1983) have indicated that mineralisation of organic matter in the surface water is faster, which results in recycling of nitrogen up to 8 times in the surface waters before it is lost from the euphotic zone. Excretion from zooplankton may also contribute to a substantial amount of $\mathrm{N}$ in the form of ammonia (Biggs 1982, Koike et al.

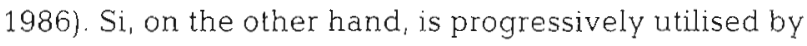


Table 5. Latitudinal variation of $\mathrm{chl} \mathrm{a}\left(\mathrm{mg} \mathrm{m}^{-2}\right)$ and $\mathrm{PP}\left(\mathrm{g} \mathrm{C} \mathrm{m}^{-2} \mathrm{~d}^{-1}\right)$ in the water column and assimilation number, AN (mg C [mg chl $]^{-1} \mathrm{~h}^{-1}$ ) during 1981 (INAEX l) and 1984-85 (INAEX IV)

\begin{tabular}{|c|c|c|c|c|c|c|c|}
\hline \multirow[t]{2}{*}{ Latitude } & \multicolumn{3}{|c|}{1982} & \multicolumn{4}{|c|}{$1984-85$} \\
\hline & $\mathrm{PP}$ & Chl a & $A N$ & Latitude & PP & Chl a & AN \\
\hline $\begin{array}{l}69^{\circ} 58^{\prime} \\
\text { (Polynia) }\end{array}$ & 0.16 & 28.9 & 0.23 & $\begin{array}{c}69^{\circ} 47^{\prime} \\
\text { (Polynia) }\end{array}$ & 1.02 & 72.27 & 0.56 \\
\hline $69^{\circ} 00^{\prime}$ & 0.23 & 15.55 & 0.62 & $69^{\circ} 03^{\prime}$ & 0.07 & 4.52 & 0.65 \\
\hline $68^{\circ} 43^{\prime}$ & 0.22 & 19.7 & 0.47 & $68^{\circ} 58^{\prime}$ & 0.45 & 16.7 & 1.12 \\
\hline $68^{\circ} 25^{\prime}$ & 0.7 & 8.25 & 3.54 & - & & & \\
\hline $67^{\circ} 46^{\prime}$ & 0.06 & 9.7 & 0.26 & - & & & \\
\hline $65^{\circ} 15^{\prime}$ & 0.21 & 7.45 & 1.17 & $64^{\circ} 42^{\prime}$ & 0.17 & 6.28 & 1.13 \\
\hline $61^{\circ} 28^{\prime}$ & 0.05 & 26.5 & 0.08 & $60^{\circ} 48^{\prime}$ & 0.25 & 4.18 & 2.49 \\
\hline $58^{\circ} 16^{\prime}$ & 0.55 & 64.35 & 0.36 & - & & & \\
\hline $52^{\circ} 48^{\prime}$ & 0.04 & 12.45 & 0.13 & - & & & \\
\hline $47^{\circ} 23^{\prime}$ & 0.23 & 8.0 & 1.2 & - & & & \\
\hline $41^{\circ} 14^{\prime}$ & 0.05 & 9.75 & 0.21 & - & & & \\
\hline $32^{\circ} 00^{\prime}$ & 0.14 & 23.6 & 0.21 & - & & & \\
\hline \multicolumn{8}{|c|}{ South of $58^{\circ} \mathrm{S}$} \\
\hline Mean & 0.29 & 21.64 & 0.93 & & 0.235 & 7.92 & 1.35 \\
\hline $\mathrm{SD}$ & \pm 0.23 & \pm 18.56 & \pm 1.11 & & \pm 0.14 & \pm 5.13 & \pm 0.69 \\
\hline \multicolumn{8}{|c|}{ North of $58^{\circ} \mathrm{S}$} \\
\hline Mean & 0.115 & 13.45 & 0.44 & & & & \\
\hline $\mathrm{SD}$ & \pm 0.08 & \pm 6.07 & \pm 0.44 & & & & \\
\hline
\end{tabular}

Table 6. Mean value of zooplankton (ml $\left.1000 \mathrm{~m}^{-3}\right)$ for 1982 to 1986 and $\mathrm{chl}\left(\mathrm{mg} \mathrm{m}^{-2}\right), \mathrm{PP}\left(\mathrm{g} \mathrm{C} \mathrm{m}^{-2} \mathrm{~d}^{-1}\right)$ and AN (mg C [mg chl] ${ }^{-1}$ $\mathrm{h}^{-1}$ ) in 1982 at every $5^{\circ}$ from $70^{\circ}$ to $20^{\circ} \mathrm{S}$ latitude

\begin{tabular}{|c|c|c|c|c|c|c|c|}
\hline $\begin{array}{l}\text { Latitude } \\
\text { degrees S }\end{array}$ & $\begin{array}{c}1982 \\
\operatorname{Jan}\end{array}$ & $\begin{array}{c}1984 \\
\text { Feb-Mar }\end{array}$ & $\begin{array}{c}1985 \\
\text { Feb-Mar }\end{array}$ & $\begin{array}{c}1986 \\
\text { Feb-Mar }\end{array}$ & PP & $\begin{array}{c}1982 \\
\mathrm{Jan} \\
\mathrm{Ch}\end{array}$ & $\mathrm{AN}$ \\
\hline $20-25$ & - & 13.25 & - & - & - & - & - \\
\hline $25-30$ & - & 12.6 & 36 & - & - & - & - \\
\hline $30-35$ & - & 6.65 & 79 & - & 0.14 & 23.6 & 0.21 \\
\hline $35-40$ & 92 & 20.9 & 105 & - & - & - & - \\
\hline $40-45$ & 29 & 37.7 & 133 & 14.6 & 0.05 & 9.75 & 0.21 \\
\hline $45-50$ & 75.5 & 79.9 & 160 & 89.7 & 0.23 & 8.0 & 0.12 \\
\hline $50-55$ & 130 & 53.5 & 228 & 194.9 & 0.04 & 12.45 & 0.13 \\
\hline $55-60$ & 453.5 & 32.6 & 565 & 79.2 & 0.55 & 64.35 & 0.36 \\
\hline $60-65$ & 92.5 & 209 & - & 47.8 & 0.05 & 26.5 & 0.08 \\
\hline $65-70$ & 32.1 & 90.1 & 196.5 & 78.9 & 0.26 & 14.9 & 1.05 \\
\hline
\end{tabular}

the diatoms whose frustules disappear rapidly from the surface waters without being quickly mineralised (Jacques 1983).

$\mathrm{PP}$ and chl a values in Antarctic waters (INAEX IV) show low but significant correlations with $\mathrm{NO}_{3}$ and $\mathrm{PO}_{4}$. These observations signify that nutrients play a vital role in phytoplankton production in Antarctic waters. But there seems to be no indication of deficiency even in some of the most productive Antarctic regions and hence it is doubtful that they may exert an influence on assimilation number of phytoplankton. ElSayed (1971) for example reported that even during a heavy phytoplankton bloom in the southwestern Weddell Sea the concentration of nutrients was still high
$\left(\mathrm{PO}_{4}, 2.02 ; \mathrm{NO}_{3}, 24.9\right.$; and $\left.\mathrm{SiO}_{3}, 68.0 \mu \mathrm{M}\right)$. The assimilation number of this bloom population was lower than $1.4 \mathrm{mg} \mathrm{C}$ (mg chl) ${ }^{-1} \mathrm{~h}^{-1}$. In the other oceanic regions in Antarctica, assimilation numbers were also low (Table 7). Contrary to some of the observatioins noted above, Fogg (1975) asserted that a low assimilation number is a characteristic of phytoplankton cells rich in nutrient. The low assimilation number cannot at present be related to any nutrients in particular. This suggests the need to study other physical and biological factors that may affect phytoplankton activity.

It has been estimated that the total daily light flux received during austral summer can exceed that of tropical waters (Holm-Hansen et al. 1977). Thus the 


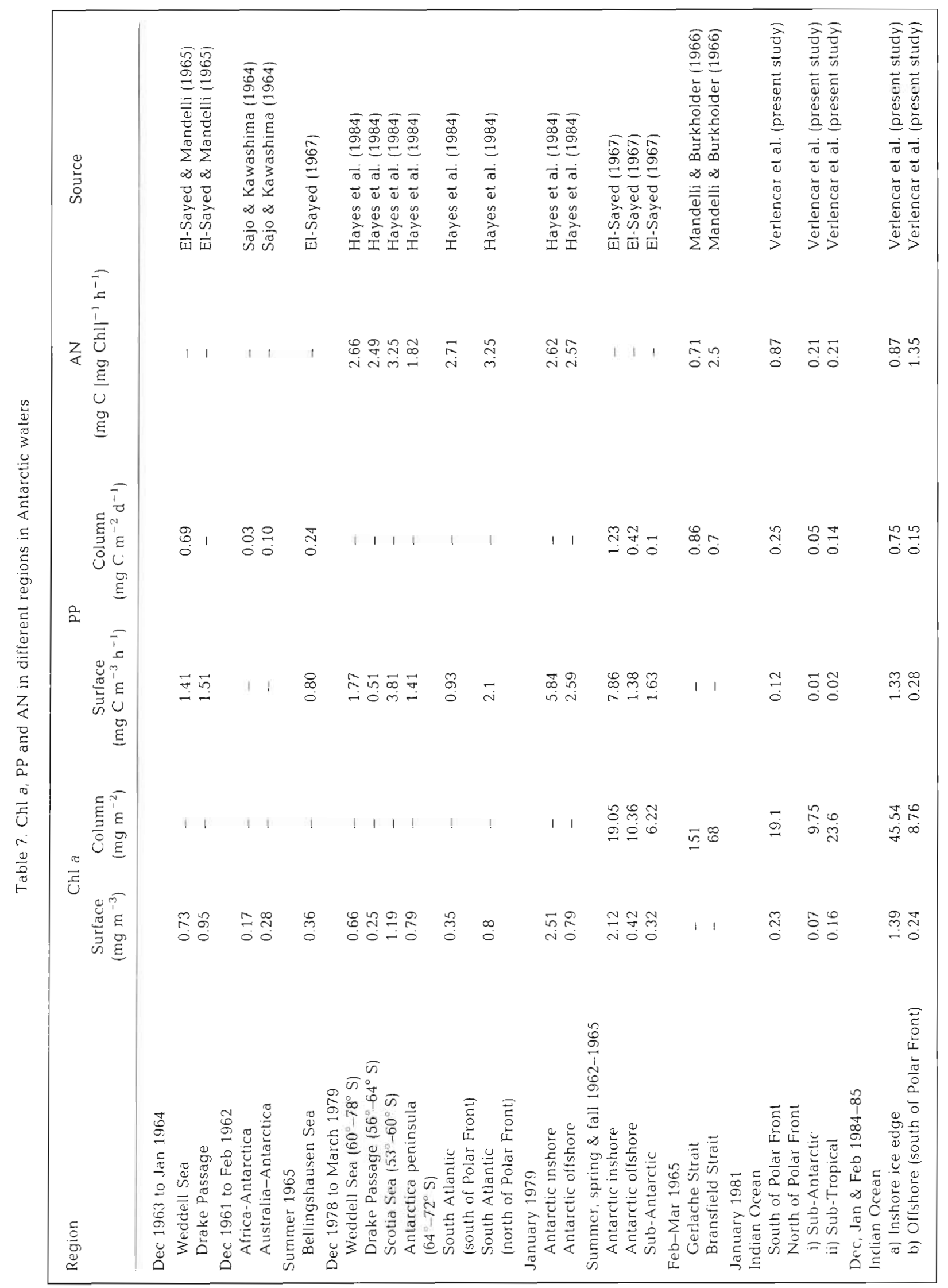


radiation at the surface is sufficient to develop phytoplankton blooms. However, low Ik values (light intensity at the onset of light saturation) during austral summer obtained by Jacques (1983) clearly illustrate the inability of Antarctic phytoplankton to use available light in the euphotic layer. Jacques (1983) and Neori \& Holm-Hansen (1982) demonstrated through their experimental results that it is temperature that sets the upper limit of growth rate to 0.6 doublings $\mathrm{d}^{-1}$. provided the radiation received is close to optimum. Under such conditions at least $10 \mathrm{~d}$ would be needed for a phytoplankton bloom. But the large fluctuations in wind speed and cloud in Antarctica (Pant 1986) may make it difficult to attain optimum conditions.

Euphausids in the Southern Oceans are dominant herbivores (Everson \& Ward 1980, Antezana \& Ray 1984). High krill concentrations are usually noted for the accompanying low standing crop of phytoplankton (Rakusa Suszczewski 1982, Uribe 1982). Our results of continuous monitoring for 2 mo at the coastal ice edge (Pant 1986) show an inverse relationship between phytoplankton biomass and zooplankton abundance, indicating that phytoplankton populations are subjected to active grazing.

However the low primary productivity observed in most of the Antarctic oceanic waters in the present study raises the question of survival of high zooplankton stocks. Fractionation studies on Antarctic phytoplankton have shown that nannoplankton $<20$ um) contributes at least $50 \%$ of the total production measured in all our studies (Matondker \& Qasim 1983, Pant 1986, Verlencar \& Paruleker 1987). Bacterial biomass in surface waters was found to range from 0.001 to $10.2 \mathrm{mg} \mathrm{C} \mathrm{m}^{-3}$ and 0.002 to $1.869 \mathrm{~g} \mathrm{C} \mathrm{m}^{-2}$ in the water column (Matondker \& Qasim 1983). Fuhrman \& Azam (1980) have estimated that bacterioplankton production in Antarctic waters could be as high as $2.9 \mathrm{mg}$ $\mathrm{C} \mathrm{m}^{-3} \mathrm{~d}^{-1}$. Sakshaug \& Holm-Hansen (1984) contend that pelagic blooms in Polar Oceans are usually dominated by fairly large chains of diatoms and for nonbloom conditions, the nannoplankton and subpopulations of still smaller organisms known as picoplankton $(<2 \mu \mathrm{m})$ and heterotrophic bacteria may form an important component of the Antarctic marine food chain (Azam et al. 1983, Weber \& El-Sayed 1987).

\section{Nutrient anomalies}

To understand the biological and physical processes, interest was focussed on the well-mixed zones of the subsurface and deep water. Using the linear part of the $\theta$-salinity plot and taking the end members as a reference for the water masses, anomalies were calculated for the non-conservative parameters like nitrate, phos- phate and silicate. These nutrients give positive and negative anomalies in the south and north of STC respectively. But these anomalies cannot be accounted for solely by remineralization of nutrients in deep waters (Fig. 10).
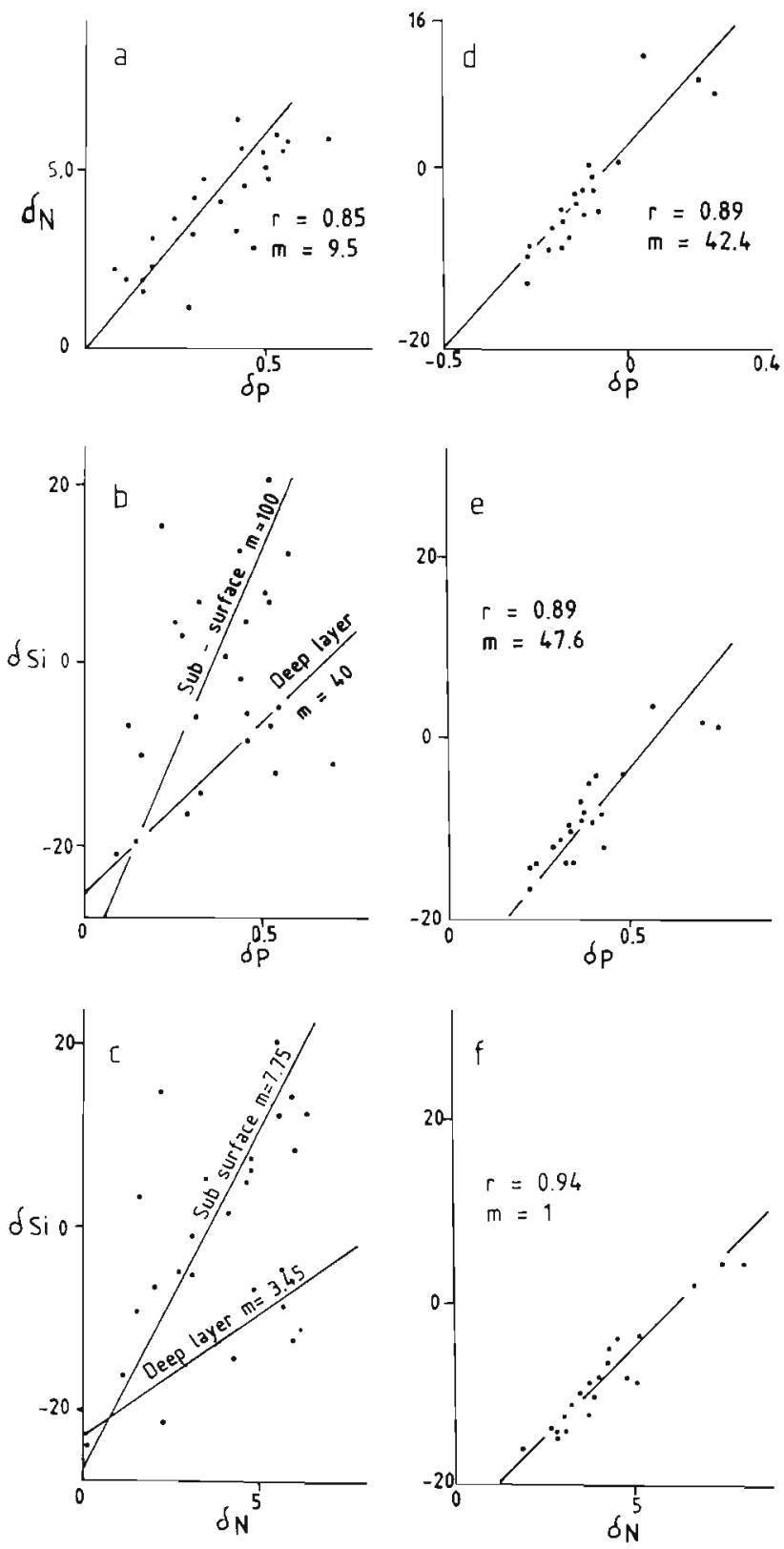

Fig. 10. Relationships of nutrient anomalies (INAEX III) (a to c) South of STC; ( $d$ to $f$ ) north of STC

The calculated positive anomalies of $\Delta N$ and $\Delta P$, in the south of STC are linearly correlated at 0.85 with a slope of 10 , which is much lower than the theoretical Redfield ratio of 16 . Le Jehan \& Treguer (1983) reported that in the subsurface and deep waters, the $\Delta \mathrm{N}: \Delta \mathrm{P}$ ratios were 13.6 and 16.8 for Antiprod 2 and 1 
cruises, respectively. Silicate anomalies in the present study exhibit 2 different slopes both with $N$ and $P$. The first slope of the $\Delta \mathrm{Si}: \Delta N(7.75)$ could reflect regeneration of $\mathrm{Si}$ in the subsurface waters and the second slope due to the further regeneration of $\mathrm{Si}$ in the deeper layer or the addition of Si by mixing with different watermasses. In the north of STC the negative anomalies of $\Delta N: \Delta P, \Delta S i: \Delta N$ and $\Delta \mathrm{Si}: \Delta \mathrm{P}$ show good correlations with a single slope. This indicates that the biological activities are masked by physical processes. In the deep and subsurface layers, $\Delta S i: \Delta N$ in the south of STC are 3 and 7 times higher, respectively, than that of the slope north of STC, which means an excess of $\mathrm{Si}$ is added by processes other than regeneration (Fig. 10). However, with respect to phosphate anomalies, the silica slopes show very little change.

\section{Nutrient-oxygen relationship}

Considerable variation was observed in the relationships between apparent oxygen utilization (AOU) and nitrate, phosphate and silicate in the south and north of STC. Points in the linear range of AOU and nutrient values are taken into consideration for calculation of oxidative ratios, based on the assumption that the regeneration processes occur within these limits. Table 8 shows that in the southern Indian Ocean, north of the STC, the $\Delta N: \Delta P$ ratio is $15.4: 1$ which is in agreement with the ratio reported by Sen Gupta et al. (1976) for the Indian Ocean, whereas in the region south of STC the $\triangle N: \triangle P$ ratio is $30 \%$ lower than that north of the STC. The $\triangle \mathrm{Si}: \Delta \mathrm{N}$ ratio for the region south of the STC is about 5 times higher than that observed north of the STC. This means that there was a 5-fold increase in silica in the region south of the STC and as postulated earlier it reflects an excess regeneration of biogenic silica in the Antarctic marine diatoms.

The results of INAEX I also show a $\Delta S i: \Delta N$ ratio more than unity in the Southern Ocean (Sen Gupta \& Qasim 1983; Table 8). Copin-Montegut \& CopinMontegut (1978) showed that the ratio of particulate biogenic Si to organic $N$ increased from 0.2 north of the Convergence to 2.0 south of the Convergence in the Indian Ocean sector. Moreover, from a hydrological model, Le Jehan \& Treguer (1983) concluded that $\Delta \mathrm{Si}: \Delta \mathrm{N}$ anomalies could range from 1 to 8 times in the Antarctic waters. These computations agree well with the $\Delta \mathrm{Si}: \Delta \mathrm{N}$ anomaly and the oxidation ratios obtained in the present study. In the Indian Ocean as a whole, north of the Convergence, $\Delta \mathrm{Si}: \Delta \mathrm{N}$ ratios may vary by a factor of 2 (Sen Gupta et al. 1976) from that proposed by Richards (1958). A zonewise decrease in the particulate N:P ratio from 19.7 to 9.7 in tropical and Antarctic waters was reported by Copin-Montegut \& Copin-Montegut (1978). These authors also observed that, while the particulate $\mathrm{C}: \mathrm{N}$ ratio remained constant in the deeper layers in the Antarctic waters, the $C: P$ ratio decreased. This corroborates well with our observations of a $30 \%$ lower N:P ratio in the Antarctic region than in the region north of the STC.

It can be stated therefore that the Si pool in the Southern Ocean is replenished by the influx of Si-rich water by vertical eddy diffusion and advection at the $\mathrm{AD}$, and the sharp decrease in its concentration around $\mathrm{AC}$ suggests high utilization with comparatively low remineralization in the surface waters or low replenishment from the bottom waters. Persistence of high $\mathrm{NO}_{3}$ and $\mathrm{PO}_{4}$ concentrations in the surface waters to the south of $A C$, on the other hand, suggest that besides the influx by the above processes, remineralization of these nutrients was high in surface waters as well (Hargrave \& Geen 1968, Ronner et al. 1983). The spatial variation in the biological productivity in the oceanic region south of $\mathrm{AC}$ cannot be accounted for by the difference in incidental radiation, water temperature, or concentration of $\mathrm{NO}_{3}, \mathrm{PO}_{4}$ and $\mathrm{SiO}_{3}$ as each of these parameters has a similar value over the entire area. The physical structure of the water column (i.e. stability and the depth of mixed layer), near freezing temperatures at the ice edge, combined with heavy grazing and rapid sinking are the most significant factors controlling phytoplankton production in the Southern Ocean (El-Sayed \& Taguchi 1981, Neori \& Holm-Hansen 1982, Jacques 1983. Sakshaug \& Holm-Hansen 1984, El-Sayed 1987). However, the sharp fall in $\mathrm{Si}$ as also the low nitrates and phosphates in the region north of $\mathrm{AC}$ may be

Table 8. Oxidative ratios of nitrate, phosphate and silicate for Indran and Antarctic Oceans. AOU: apparent oxygen utílisation

\begin{tabular}{|lccccc|}
\hline Region & $\Delta \mathrm{AOU}$ & $\Delta \mathrm{SiO}_{2}$ & $\mathrm{AN}$ & $\Delta \mathrm{P}$ & Source \\
\hline Northwestern Indian Ocean & 280 & 40 & 16 & 1 & Sen Gupta et al. (1976) \\
Antarctic Waters & & & & & \\
$\quad$ INAEX I & 285 & 58 & 19 & 1 & Sen Gupta \& Qasim (1983) \\
North of Convergence (INAEX III) & 220 & 16 & 15.4 & 1 & Present study \\
South of Convergence (INAEX III) & 336 & 53 & 10 & 1 & Present study \\
\hline
\end{tabular}


responsible for the low biological productivity in the Subantarctic and Subtropical regions (Jacques 1983). Nevertheless, the high levels of dissolved nutrients and the regeneration ratios suggest that the nutrients, especially the silicates, have an important relationship with the Antarctic diatom populations (Walsh 1971 , Kennett 1977, Copin-Montegut \& Copin-Montegut 1978, Allanson et al. 1981, Le Jehan \& Treguer 1983, 1985). But they exert no primary control on the overall phytoplankton activity (Sakshaug \& Holm-Hansen 1984, El-Sayed 1987).

Acknowledgements. We thank Dr B. N. Desai, Director, NIO for his interest in this work, Drs R. Sen Gupta and Arun Parulekar for their encouragement and Drs A. Pant, S. W. A. Naqui, K. J. Mathew and S. G. P. Matondkar for allowing us to make use of their data. Thanks are also due to Prof. S. Z. El-Sayed and his colleagues from Texas A \& M Univ, USA and Dr G. Copin-Montegut, Laboratoire De Physique E Chimie Marine, France, for their expert comments on the manuscript

\section{LITERATURE CITED}

Allanson, B. R., Hart, R. C., Lutjerhams, J. R. E. (1981). Observations on the nutrients, chlorophyll and primary production of Southern Oceans south of Africa. S. Afr. J. Antarct. Res. 10: 3-14

Alvarez-Borrego, S., Guthrie, D., Culberson, C. H., Park, P. K. (1975). Test of Redfield's model for oxygen nutrient relationships using regression analysis. Limnol. Oceanogr. 20: 795-805

Antezana, T., Ray, K. (1984). Active feeding of Euphausia superba in a swarm north of Atlantic Island. J. Crust. Biol. 4: $142-155$

Azam, F., Field, J. G., Gray, J. S., Meyer-Reil, L.-A., Thingstad, F. (1983). The ecological role of water-column microbes in the sea. Mar Ecol. Prog. Ser 10: 257-263

Benson, B. B., Krause, D. Jr (1984). The concentration and isotopic fraction of oxygen dissolved in fresh and sea water in equilibrium with atmosphere. Limnol. Oceanogr. 29: $620-632$

Biggs, D. C. (1982). Zooplankton excretion and $\mathrm{NH}_{4}{ }^{+}$cycling in near-surface waters of the Southern Ocean. 1. Ross Sea, austral summer 1977-1978. Polar Biol. 1: 55-67

Broecker, W. S., Takahashi, T., Li, Y H. (1976). Hydrography of central Atlantic. I. Two-degree discontinuity. Deep Sea Res. 23: 1083-1104

Copin-Montegut, C., Copin-Montegut, G. (1978). The chemistry of particulate matter from south Indian and Antarctic Oceans. Deep Sea Res. 25: 911-931

Curl, H. Jr, Small, L. F. (1965). Variation in photosynthetic assimilation ratio in natural, marine phytoplankton communities. Limnol. Oceanogr. 10: 67-73

Currie, R. I. (1963). The Indian Ocean Standard Net. Deep Sea Res. 10: $27-32$

Deacon, G. E. R. (1977). Seasonal variations in the water temperature and salinity near South Georgia 1925-1937. Inst. Oceanogr. Sci. Rep. No. 49, p. 1-29

Deacon, G. E. R. (1982). Physical and biological zonation in the Southern Ocean. Deep Sea Res. 29: 1-16

Deacon, G. E. R. (1983). Kerguelen, Antarctic and Subantarctic. Deep Sea Res. 30:77-81
De Master, D. J. (1981). The supply and accumulation of silica in the marine environment. Geochim. Cosmochim. Acta 45: $1715-1732$

El-Sayed, S. Z. (1967). On the productivity of the south-west Atlantic Ocean and the water west of Antarctic Peninsula. In: Schmitt, W., Llano, G. A. (eds.) Biology of Antarctic Seas III. Antarct. Res. Ser. 2: 5-47

El-Sayed, S. Z. (1971). Observations on phytoplankton bloom in the Weddell Sea. In: Llano, G. A., Wallen, I. E. (eds.) Biology of Antarctic Seas IV. Antarct. Res. Ser. 17: 301-312

El-Sayed, S. Z. (1987). Biological productivity of the Antarctic waters: present paradoxes and emerging paradigms. In: El-Sayed, S. Z., Tomo, A. P. (eds.) Antarctic aquatic biology. BIOMASS scient. Ser 7: 1-22

El-Sayed, S. Z., Mandelli, E. F. (1965). Primary production and standing crop of phytoplankton in the Weddell Sea and Drake Passage. In: Llano, G. A. (ed.) Biology of Antarctic Seas II. Antarct. Res. Ser 5: 87-124

El-Sayed, S. Z., Taguchi, S. (1981). Primary production and standing crop of phytoplankton along the ice edge in the Weddell Sea. Deep Sea Res. 28: 1017-1032

El-Sayed, S. Z., Weber, L. H. (1982). Spatial and temporal variation in phytoplankton biomass and productivity in the southern Atlantic and Scotia Sea. Polar Biol. 1: 83-90

El-Sayed, S. Z., Biggs, D. C., Holm-Hansen, O. (1983). Phytoplankton standing crop, primary productivity and near surface nitrogenous fields in the Ross Sea. Deep Sea Res. 30: $871-886$

Everson, I., Ward, P. (1980). Aspects of Scotia Sea zooplankton. Biol. J. Linn. Soc. 14: 93-101

Fofonoff, N. P., Millard, Jr (1983). Algorithms for the computation of fundamental properties. UNESCO Tech. Pap. mar. Sci. $44: 38-44$

Fogg, G. E. (1975). Algal cultures and phytoplankton ecology. Univ. Wisconsin Press, Madison

Fogg, G. E. (1977). Aquatic primary production in the Antarctic. Phil. Trans. R. SoC. B 279: 27-38

Friederich, G. E., Codispoti, L. A. (1981). The effects of mixing and regeneration on the nutrient content of upwelling waters off Peru. In: Richards, F. A. (ed.) Coastal upwelling. American Geophysical Union. Washington, D.C. p. 221-227

Fuhrman, J. A., Azam, F. (1980). Bacterioplankton secondary production estimates for coastal waters of British Columbia, Antarctia and California. Appl. environ. Microbiol. 39: 1085-1095

Gamberoni, L., Geronimi, J., Jeannin, P. F., Murail, J. F. (1982). Study of frontal zones in the Crozet-Kerguelen region. Oceanologica Acta 5: 289-299

Gordon, A. L., Goldberg, R. D. (1970). Circumpolar characteristics of Antarctic waters. In: Bushnell, V. E. (ed.) Antarctic Map Folio Series. American Geographical Society, New York, p. 13

Grasshoff, K. (1976). Methods of seawater analysis. Verlag Chemie, Weinheim

Hargrave, B. T., Geen, G. H. (1968). Phosphorus excretion by zooplankton. Limnol. Oceanogr, 13: 332-342

Hasle, G. R. (1969). An analysis of phytoplankton of the Pacific Southern Ocean: abundance, composition and distribution during the Brateeg Expedition 1947/48. Hvalråd Skr. 52: $1-168$

Hayes, P. K.. Whitaker, T M., Fogg, G. E. (1984). The distribution and nutrient status of phytoplankton in the Southern Ocean between 20 and $70^{\circ} \mathrm{W}$ Polar Biol. 3: 153-165

Holm-Hansen, O., El-Sayed, S. Z., Franceschini, G. A., Cuhel, K. (1977). Primary production and the factors controlling phytoplankton growth in the Antarctic Seas. In: Llano, G. 
A. (ed.) Adaptations within Antarctic ecosystems. Smithsonian Institution, Washington, D.C., p. 11-50

Jacques, G. (1983). Some ecophysiological aspects of Antarctic phytoplankton. Polar Biol. 2: 27-33

Kennett, J. P. (1977). Cenozoic evolution of Antarctic glaciation, the circum-Antarctic Ocean, and their impact on global paleoceanography. J. geophys. Res. 82: 384.3-3859

Koike, I., Holm-Hansen, O., Biggs, D. C. (1986). Inorganic nitrogen metabolism by Antarctic phytoplankton with special reference to ammonia cycling. Mar. Ecol. Prog. Ser. 30 : 105-116

Kuramoto, S., Koyama, K. (1982). Preliminary report of the oceanographic observations in the 22nd Japanese Antarctic Research Expedition (1980-1981). Mem. natl Inst. polar Res., Tokyo (Spec. Issue) 23: 5--12

Le Jehan, S., Treguer, P. (1983). Uptake and regeneration $\Delta$ Si $\Delta N / \Delta P$ ratios in the Indian Sector of the Southern Ocean. Originality of biological cycle of silicon. Polar Biol. 2: $127-136$

Le Jehan, S., Treguer, P. (1985). Distribution of inorganic nitrogen, phosphorus, silicon and dissolved organic matter in surface and deep waters of the Southern Ocean. In: Siegfried, W. R., Condy, P. R., Laws, R. M. (eds.) Antarctic nutrient cycles and food webs. Springer Verlag, Berlin, p. $22-29$

Lutjeharms, J. R. E., Walters, N. M., Allanson, B. R. (1985). Oceanic frontal systems and biological enhancement. In: Siegfried, W. R., Condy, P. R., Laws, R. M. (eds.) Antarctic nutrient cycles and food webs. Springer Verlag, Berlin, p. $11-21$

Mandelli, E. F., Burkholder, P. R. (1966). Primary productivity in the Gerlache and Bransfield Straits of Antarctica. J. mar. Res. 24: 15-27

Mathew, K. J. (1986). Spatial distribution of krill (Euphausia superba) and other zooplankton off Queen Maud Land, Antarctica. Third Indian Expedition to Antarctica Scientific Rept. Dept. of Ocean Development, New Delhi, Tech. Pub. 3: $149-150$

Mathew, K. J., Vincent, D. (1986a). Daily variation in the abundance of zooplankton in the coastal waters of Queen Maud Land, Antarctica, during summer 1983-84. Third Indian Expedition to Antarctica, Scientific Rep., Dept of Ocean Development, New Delhi, Tech. Pub, 3: 97-108

Mathew, K. J., Vincent, D. (1986b). Latitudinal distribution of zooplankton in the southern ocean with special reference to euphausids. Third Indian Expedition to Antarctica Scientific Rep., Dept. of Ocean Development, New Delhi, Tech Pub. 3: 161-174

Matondkar, S. G. P., Qasim, S. Z. (1983). Some observations on the biological productivity of Antarctic waters. First Indian Expedition to Antarctica Scientific Rep., Dept. of Ocean Development, New Delhi, Tech. pub. 1: 191-197

McConville, M. J., Mitchell, C., Wetherbee, R. (1985). Patterns of carbon assimilation in a microalgal community from annual sea ice, East Antarctic. Polar Biol. 4: 135-141

Nelson, D. M., Georing, J. J., Boissean, D. W (1981). Consumption and regeneration of silicic acid in three coastal upwelling systems. In: Richards, F. A. (ed.) Coastal upwelling. American Geophysical Union, Washington, D.C., p. $242-256$

Neori, A., Holm-Hansen, O. (1982). Effect of temperature on the rate of photosynthesis in Antarctic phytoplankton. Polar Biol. 1: 33-38

Pant, A. (1986). Studies on Antarctic phytoplankton. Third Indian Expedition to Antarctica Scientific Rep., Dept of Ocean Development, New Delhi, Tech. Pub. 3: 87-93

Platt, T., Subba Rao, D. V (1975). Primary production of marine microphytes. In: Cooper, J. P. (ed.) Photosynthesis and productivity in different environments. Cambridge Univ. Press, London, p. 249-280

Probyn, T A., Painting, S. J. (1985). Nitrogen uptake by size fractionated phytoplankton populations in Antarctic surface waters. Limnol. Oceanogr. 30: 1327-1332

Rama Raju, D. V., Somayajulu, Y K. (1983). Some physical characteristics of the Antarctic and western Indian Ocean. Scientic Rep. First Indian Expedition to Antarctica, Dept of Ocean Development, New Delhi, Tech. Publ. 1: 53-61

Rakusa-Suszczewski, S. (1982). Feeding of Euphausia superba Dana under natural conditions. Pol. polar Res. 3: 289-297

Richards, F. A. (1958). Dissolved silicate and related properties of some western north Atlantic and Caribbean Waters. J. mar. Res. 17: 449-465

Ronner, U., Sorensson, F., Holm-Hansen, O. (1983). Nitrogen assimilation by phytoplankton in the Scotia Sea. Polar Biol. 2: $137-147$

Saijo, Y., Kawashima, T. (1964). Primary production in the Antarctic Ocean. J. Oceanogr. Soc. Japan 19: 22-28

Sakshaug, E., Holm-Hansen, O. (1984). Factors governing pelagic production in Polar Oceans. In: Holm-Hansen, $O$., Bolis, L., Gilles, R. (eds.) Marine phytoplankton productivity. Springer-Verlag, Berlin, p. 1-18

Sen Gupta, R., Rajgopal, M. D., Qasim, S. Z. (1976). Relationship between dissolved oxygen and nutrients in the northwestern Indian Ocean. Ind. J. mar. Sci. 5: 201-211

Sen Gupta, R., Qasim, S. Z. (1983). Chemical oceanographic studies along section from $32^{\circ} \mathrm{S}$ to Antarctica in the southwestern Indian Ocean. Scientific Rep. First Indian Expedition to Antarctica, Dept of Ocean Development, New Delhi Tech. Publ. 1: 69-77

Slawyk, G. (1979). ${ }^{13} \mathrm{C}$ and ${ }^{15} \mathrm{~N}$ uptake by phytoplankton in the Antarctic upwelling area: results from Antiprod I cruise in the Indian ocean Sector. Aust. J. mar. Freshwat. Res. 30 $431-448$

Smith, W. O. Jr, Nelson, D. M. (1985). Phytoplankton biomass near the receding ice-edge in the Ross Sea. In: Siegfried, W. R., Condy, P. R., Laws, R. M. (eds.) Antarctic nutrient cycles and foodwebs. Springer-Verlag, Berlin, p. 70-77

Sommer, U. (1986). Nitrate and silicate competition among Antarctic phytoplankton. Mar Biol. 91: 345-352

Sommer, U., Stabel, H. H. (1986). Near surface nutrient and phytoplankton distribution in the Drake Passage during early December Polar Biol. 6: 107-110

Strickland, J. D. H., Parsons, T R. (1972). A practical handbook of seawater analysis. Bull. Fish. Res. Bd Can. 167

Subba Rao, D. V (1969). Asterionella japonica bloom and discoloration off Waltarr, Bay of Bengal. Limnol. Oceanogr 14: $632-634$

Thomas, W. H. (1970). A nitrogen deficiency in tropical Pacific oceanic phytoplankton: photosynthetic parameters in poor and rich water Limnol. Oceanogr 15: 380-385

Uribe, E. (1982). Influence of phytoplankton and primary production of Antarctic waters in relationship with the distribution and behaviour of krill. Publ. Inst. Antarct. Chil. Ser Cie. No 28, p. 147-163

Verlencar, X. N., Paruleker, A. H. (1987). Nutrients and phytoplankton production in the Southern Ocean in a section 10 to $52^{\circ} \mathrm{E}$ in the Indian Ocean. Fourth Indian Scientific Expedition to Antarctica, Dept of Ocean Development, New Delhi, Tech. Publ. 4: 159-167

Walsh, J. J. (1971). Relative importance of habitat variables in predicting the distribution of phytoplankton at the ecotone of Antarctic upwelling ecosystem. Ecol. Monogr 41. 291-309 
Weber, L. H., El-Sayed, S. Z. (1987). Phytoplankton biomass and productivity in the Bransfield Strait and Elephanta Island region of the Southern Ocean in January 1987 Antarctic J. U.S. 22: 204-205

Wyrtki, K. (1960). The Antarctic circumpolar current and the Antarctic Polar Front. Dtsch. Hydrogr. Z 13: 153-1.74

This article was submitted to the editor
Wyrtki, K. (1973). Physical aceanography of the Indian Ocean In: Zeitschel, B. (ed.) The biology of the Indian Ocean. Springer-Verlag, Berlin, p. 18-36

Yamaguchi, Y., Shibata, Y. (1982). Standing stock and distribution of phytoplankton chlorophyll in the Southern Ocean south of Australia. Trans. Tokyo Univ. Fish. 5: 111-128

Manuscript first received: July 5, 1988

Revised version accepted: November 21, 1989 